\title{
Architecture of Jesuit Churches in the Former Polish-Lithuanian Commonwealth, 1564-1773
}

\author{
Andrzej Betlej \\ Jagiellonian University, Cracow \\ andrzej.betlej@uj.edu.pl
}

\begin{abstract}
The article presents the history and accomplishments of Jesuit architecture in the Polish-Lithuanian Commonwealth from the late sixteenth to the late eighteenth century. The author sees Jesuit architecture as a distinct and homogeneous element within Polish architecture. The paper starts with a brief presentation of the existing research in the subject. It moves on to enumerate the activities of the Society in the field of construction, divided into three major booms: the first roughly between 1575 and 1650 , the second between 1670 and 1700 , and the third from 1740 to 1770 , divided by periods of relative decline caused by a succession of devastating wars. The paper identifies the most important architects involved in the construction of Jesuit churches, as well as their most notable works. The paper ends with a brief note concerning the fate of the Jesuit churches after the suppression of the Society and the partitions of Poland.
\end{abstract}

\section{Keywords}

architecture - Poland - Polish-Lithuanian Commonwealth - Jesuit churches

Jesuit architecture represents, by way of a pars pro toto, the architecture of the Polish-Lithuanian Commonwealth in general. As a distinct and homogeneous part of the panorama of Polish architecture, Jesuit churches certainly deserve a separate study. Unfortunately, it is hard to present a comprehensive, consistent body of research on Jesuit architecture in Poland. Although art historians do have at their disposal a fairly large number of publications on individual Jesuit churches, an overall, all-encompassing perspective is lacking. We should mention the impressive elaboration on the Society's history published in the

(C) BETLEJ, 2018 | DOI:10.1163/22141332-00503002

This is an open access article distributed under the terms of the prevailing CC-BY-NC license at the time of publication. 
beginning of the twentieth century by Stanisław Załęski, S.J. (1843-1908) entitled Jezuici $w$ Polsce (Jesuits in Poland). ${ }^{1}$ The work is of great importance as it was based on archival materials, most of which were lost or destroyed during the First and the Second World Wars. Another Jesuit, Stanisław Bednarski (1896-1942), began research just before World War II, but his work was cut short by the conflict.

After 1945, due to the new geopolitical situation, the research could continue only in a very limited scope. Scholars have to realize that about seventy percent of Polish artistic heritage is located in the east, beyond the present borders of Poland. These lands effectively became "off limits" for Polish researchers, closed off by the new border which served as the inner "iron curtain" within the eastern bloc. Soviet researchers did not tackle the "alien, Western cultural heritage" in their studies, and if they did, the results were flawed by ideological and doctrinal correctness, even as they were, at the same time, often methodologically naive. Meanwhile, the systematic demolition of historical and architectural monuments was ongoing. I do not mean just the Stalinist era of the 1930 and the period immediately following World War II. Ecclesiastical architecture (including Jesuit buildings) was being destroyed even in the 1980 s as part of a planned, active battle against the church, in the course of which all its visible signs were to be removed.

Consequently, research on Jesuit architecture focused mostly upon the monuments that remained within the present borders of Poland. ${ }^{2}$ Much research was done, notably upon the Jesuit church in Cracow-the actual name of the architect of which was the subject of a lively dispute between Adam Małkiewicz and Mariusz Karpowicz (1934-2015). ${ }^{3}$ Churches in Kalisz and Święta Lipka were analyzed, and an in-depth study of the Sandomierz

1 Stanisław Załęski, Jezuici w Polsce 1564-1772 (Cracow: WAM, 1905, vol. 1-4); Stanisław Załęski, Jezuici w Polsce porozbiorowej 1772-1820 (Cracow: WAM, 1907, vol. 1-2).

2 In this paper, I excluded the research related to the buildings located within the region of Silesia, joined to Poland after 1945. For this part of Jesuit artistic heritage see: Silesia Jesuitica. Kultura i sztuka zakonu jezuitów na Śląsku i w Hrabstwie Kłodzkim (1580-1776), ed. Dariusz Galewski and Anna Jezierska (Wrocław: Stowarzyszenie Historyków Sztuki, 2012); Jesuits and Universities Artistic and Ideological Aspects of Baroque Colleges of the Society of Jesus: Examples from Genoa and Wroctaw, ed. Giacomo Montanari and Arkadiusz Wojtyła and Małgorzata Wyrzykowska (Wrocław: Wydawnictwo Uniwersytetu Wrocławskiego, 2016).

3 Adam Małkiewicz, "Kościół śś. Piotra i Pawła w Krakowie: Dzieje budowy i problem autorstwa," Zeszyty naukowe UJ:Prace z historii sztuki 5 (1967): 43-86; Adam Miłobędzki, Architektura polska XVII wieku (Warsaw: Instytut Sztuki PAN, 1980, vol. 1), 108-15; Mariusz Karpowicz, Matteo Castello: L'architetto del primo Barocco a Roma e in Polonia (Ticino: Ticino Management SA, Edizioni Arte e Storia, 2003), 93-147; Adam Małkiewicz, "Trevano czy Castello autorem 
college was carried out. Jerzy Paszenda, S.J. (1932-2012) played a special role in studying the heritage of the Jesuit order. He co-authored a dictionary of Jesuit artists, ${ }^{4}$ and the monographs on the aforementioned churches. The researcher, who used as his main resource the archives of the Archivum Romanum Societatis Iesu (to be exact, their pre-World War II photocopies), diligently studied and recorded the history of each project. The only criticism of his work is that his diligent study of sources is sometimes uncoupled from an analysis of artistic quality. His work has been collected in five volumes of a series entitled "Budowle jezuickie w Polsce" ("Jesuit buildings in Poland"). ${ }^{5}$

Paszenda was not the only person to study the subject. We should also note the monographs of Stanisław Solski $(1622-1701)^{6}$ and Bartłomiej Nataniel Wąsowski $(1617-87) \cdot{ }^{7} \mathrm{~A}$ brief discussion on the influence of Jesuit architecture on the art of the Grand Duchy of Lithuania was published by Andrzej Baranowski, back in the days when access to the monuments was still limited. ${ }^{8}$ The state of research on Jesuit-related arts changed towards the end of the 1980s. Access to the actual artworks and monuments opened up new possibilities, but it was not until the 1990s that monument stock-taking and cataloguing activities were undertaken in the former eastern lands and these efforts were further developed by Polish researchers. In that period, for example, monographs were prepared on Ostroh (Ostróg), ${ }^{9}$ Lviv (Lwów), ${ }^{10}$ Vilnius

ostatniej fazy budowy kościoła śś. Piotra i Pawła w Krakowie?," Folia historiae artium series nova 2/3 (1996-97): 81-108.

Jan Poplatek, Jerzy Paszenda, Stownik jezuitów artystów (Cracow: Wydawnictwo WAM, 1972).

5 Jerzy Paszenda, Budowle jezuickie w Polsce (Cracow: Wydawnictwo waM, 1999-2013, vol. 1-5).

$6 \quad$ Stanisław Solski. Architekt Polski, ed. Józef Burszta and Czesław Łuczak (Wrocław: Ossolineum, 1969), v-XXXII.

Jerzy Baranowski, Barttomiej Nataniel Wasowski, teoretyk i architekt XVIII w. (Wrocław: Ossolineum, 1975).

8 Andrzej Baranowski, "Rola kościołów jezuickich w rozwoju architektury Wielkiego Księstwa Litewskiego," in Podtug nieba i zwyczaju polskiego. Studia z historii architekturom sztuki i kultury ofiarowane Adamowi Mitobędzkiemu (Warsaw: Państwowe Wydawnictwo Naukowe, 1988), 286-95.

Jerzy Paszenda, "Architektura kolegium jezuitów w Ostrogu," in Paszenda, Budowle, vol. 2, 305-334; Andrzej Betlej, "Niech przyjdzie tu Witruwiusz wraz ze swoim następcami. Kilka uwag na temat kościoła Jezuitów w Ostrogu," Roczniki humanistyczne KUL: Historia sztuki 54 (2006): 189-224.

$10 \quad$ Andrzej Betlej, "Kościół p.w. śś. Piotra i Pawła oraz dawne kolegium ks. Jezuitów," in Materiaty do dziejów sztuki sakralnej na ziemiach wschodnich dawnej Rzeczypospolitej. Kościoły i klasztory Lwowa z okresu przedrozbiorowego (2), ed. Jan Ostrowski, vol. 20 (Cracow: Międzynarodowe Centrum Kultury, 2012), 71-132. 
(Wilno), ${ }^{11}$ and Minsk (Mińsk). ${ }^{12}$ A separate study was devoted to Giovanni Maria Bernardoni (c.1541-1605), thanks to the discovery of a collection of his designs in the Kiev (Kijów) archives. ${ }^{13}$ Unfortunately, Polish monuments of Jesuit architecture remain largely unknown to Western scholars. This is due to the language barrier, as most studies have not been translated or summarized in any conference language, with the exception of the works of Richard Bösel, who not only mentions, but in some cases also discusses some of the endowments in the lands of the Polish-Lithuanian Commonwealth. ${ }^{14}$

The current research of Polish art historians focuses largely upon eighteenth-century architecture. Jesuit churches were described during the aforementioned stock-taking and cataloguing campaign, and Jesuit works are an important element in the discussions concerning, for instance, the socalled "Vilnius Rococo" architecture. ${ }^{15}$ Over the last decade, we saw the appearance of monographs on Jesuit artists - for instance the wood-carver Thomas Hutter $(c .1696-1745)^{16}$ and the architect Paweł Giżycki $(1692-1762){ }^{17}$ while

11 Jerzy Paszenda, "Kościół p.w. Św. Kazimierza w Wilnie," in Paszenda, Budowle, 4:427-6o.

12 Jerzy Paszenda, "Kolegium jezuickie w Mińsku," in Paszenda, Budowle, 2:273-304.

13 L'architetto Gian Maria Bernardoni sJ tra l'Italia e le terre dell'Europa Centro-Orientale, ed. Sante Garciotti and Jerzy Kowalczyk (Roma: Fondazione Giorgio Cini - Editrice “Calamo," 1996).

14 Richard Bösel, "Giacomo Briano. Der Architekt der Lemberger Jesuitenkirche," in Druhij Miznarodnyj Konhres Ukrajinistiw, Lviv, 22-28.08.1993. Dopowidi ta powidomlennia. Istoriohrafia ukrajinoznastwa, ennolohija, kultura (Lviv, 1994), 184-89; Richard Bösel, "Grundsatzfragen und Fallstudien zur jesuitischen Bautypologie," in: Die Jesuiten in Wien. Zur Kunst und Kulturgeschichte der Österreichischen Ordensprovinz der "Gesellschaft Jesu" im 17. und 18. Jahrhundert, ed. Herbert Karner and Werner Telesko (Wien: Verlag der Österreichischen Akademie der Wissenschaften, 2003), 208-9; Richard Bösel, "Larchitettura della Compagnia di Gesù in Europa," in Ignazio e l'Arte dei gesuiti, ed. Giovanni Sale (Milano: Jaca Books, 2003), 65-122; Richard Bösel, "Jesuitenarchitektur - zur Problematik ihrer Identität," in Bohemia Jesuitica 1556-2006, ed. Petronilla Cemus (Praha: Karolinum, 2010), 1330-31. See also: Thomas DaCosta Kaufmann, Court, Cloister \& City. The Art and Culture of Central Europe 1450-180o (London: George Weidenfeld \& Nicolson Ltd. The Orion Publishing House, 1995), 217; Paolo Ferrari Agri, "La chiesa dei ss. Pietro e Paolo a Cracovia," in Architettura della Campagna Ignaziana nei centri antichi italiani, ed. Giuseppe Rocchi Coopmans de Yoldi (Firenze: Alinea 1999), 87-104.

15 Jerzy Kowalczyk, "Barocke Sakralarchitektur in Wilna," in Barocke Sakralarchitektur in Wilna: Verfall und Erneuerung, ed. Andrea Langer and Dietmar Popp (Marburg: HerderInstitut Marburg, 2002), 23-42.

16 Jakub Sito, Thomas Hutter, rzeźbiarz późnego baroku (Warszawa-Przemyśl: Instytut Sztuki PAN, 2001).

17 Andrzej Betlej, Pawet Gizycki sJ: Architekt polski xvıII wieku (Cracow: Societas Vistulana, 2003). 
a monograph on Giacomo Briano (1589-1649) is in progress. Significantly, Encyklopedia wiedzy o jezuitach na ziemiach Polski i Litwy 1564-1995 (Encyclopaedia of knowledge about Jesuits in Poland and Lithuania 1564-1995) ${ }^{18}$ was published at the time.

The years between 1564 (when the first Jesuits arrived in Poland) and 1772-73 (when Poland was partitioned and the Society was suppressed) were of particular importance for the shaping of the Polish architectural landscape. The intensity of building activity around the year 1600 was the result of the excellent economic situation of the Polish-Lithuanian Commonwealth at that time and the intensity of Counter-Reformation projects. Jesuits played an important role in this process, in particular by creating a network of schools for the country's nobility (collegia nobilia). ${ }^{19}$ Nevertheless, even during the deep crisis that affected the Polish economy after a series of devastating wars in the middle and at the end of the seventeenth century, means were found for new architectural foundations. The second half of the seventeenth century became a period of "re-Catholicization" of the Commonwealth. After wars with Orthodox Russia, Protestant Sweden, and the Muslim Ottoman Empire, Poland found its identity in cultural attachment to the Roman Catholic religion.

The next period of economic prosperity, between 1740 and 1770, saw another building boom in Poland, also attributable to the lasting peace of those years. Vigorous building activity in the Commonwealth created a need for architects to carry out the numerous commissions, who were expected to meet various requirements, depending on the affluence, education, and artistic consciousness of their clients. The most powerful of these patrons, representing the elite of the state authorities or the higher clergy, could usually boast fairly extensive knowledge in the field of architecture, acquired for the most part by reading architectural treatises and by journeys to the main artistic centers of Europe. ${ }^{20}$ An important aspect for the erection and then decoration of the Jesuit churches was the fact that most representatives of the Polish aristocracy began

18 Encyklopedia wiedzy o Jezuitach na ziemiach Polski i Litwy 1564-1995, ed. Ludwik Grzebień (Cracow: Wydawnictwo WAM, 1996).

19 Justyna Łukaszewska-Haberkowa, Pierwsze pokolenie polskich jezuitów w świetle biografii i egzaminów (Cracow: Wydawnictwo WAM, 2013), Justyna Łukaszewska-Haberkowa, Wptyw pierwszego pokolenia polskich jezuitów na życie kulturalne i religijne Rzeczypospolitej Obojga Narodów w latach 1564-1608 (Cracow: Wydawnictwo WAM, 2014).

20 Piotr Krasny, "Architecture in Poland 1572-1764," in Land of Winged Horsemen: Art in Poland 1572-1764, ed. Jan Ostrowski (Alexandria: Art Services International, 1999), 81 and 89 . 
their education in Jesuit colleges, while Jesuit churches became mausolea of prominent princely and noble families, such as those in Nesvizh (Nieśwież), Cracow, and Lviv. $^{21}$

The first Jesuits to settle in Poland in 1564 belonged initially to the Jesuit province of Austria. In 1575, a separate province of Poland was formed, covering all the lands of the Polish Commonwealth. At the beginning of the seventeenth century, the province was subdivided into the province of Poland and the province of Lithuania - the latter also covering the Mazovia region in central Poland. A rapid development of the Society's establishments took place, although it was slowed down by Poland's wars against Russia, Sweden, and the Ottoman Empire. In the mid-seventeenth century, the number of Jesuits in the region decreased by forty percent. In 1756, the assistancy of Poland was formed, while the provinces of Greater Poland, Lesser Poland, Mazovia, and Lithuania were also established in the $1750 \mathrm{os}$. In 1773, when the order was suppressed, it survived until the early nineteenth century in the easternmost areas of Poland (the region earlier annexed by the Russian empire during the First Partition). ${ }^{22}$

The Jesuits soon gained great popularity in Poland. Although initially they were established within or next to existing churches, usually in the Gothic style, typically within several years they replaced those old churches with newly erected ones. This pattern provided a strong impulse for the development of ecclesiastical architecture in Poland. Polish architecture at the time was rather uniquely situated, as throughout most of the fifteenth century the Gothic style remained the dominant mode of ecclesiastical buildings, with only very rare exceptions. Now, the new Jesuit churches represented a new, up-to-date stylistic mode.

It should be noted that in the initial period of the development of Jesuit architecture in Poland, architects as such did not enjoy particularly high esteem. Indeed, in the sixteenth and seventeenth centuries, people often failed to make the distinction between an architect and a stonemason. The history of the Society's architecture in Poland can be described as situated between tradition and modernity. By necessity, the buildings presented in this article are merely a selection of major examples—it would not be possible to discuss

21 Andrzej Betlej, Sibi, Deo, Posteritati:Jabtonowscy a sztuka w XVIII wieku (Cracow: Societas Vistulana, 2010), 111-30.

22 Poplatek and Paszenda, Stownik, 65-69; see also Jerzy Paszenda, "Geografia budowli jezuickich w Polsce," in Paszenda, Budowle, 1:15-24; Jerzy Paszenda, "Kościoły jezuitów w dawnej asystencji polskiej," in Silesia jesuitica, ed. Dariusz Galewski and Anna Jezierska (Wrocław: Stowarzyszenie Historyków Sztuki, 2012), 85-92. 
the nearly one hundred churches and colleges (not to mention lesser establishments also in their possession).

In the initial period of the development of Jesuit architecture in Poland, the first superior provincial contracted Giuseppe Brizzio (1533-1604) and Giovanni Maria Bernardoni (c.1541-1605), two Jesuit architects who had previously worked in Rome under the guidance of Giovanni Tristano (1515-75). The former stayed and worked in Poland between 1575 and 1587 , the latter from 1583 to 1605. Both prepared numerous designs — not all of them realized - while also supervising work on many projects of varying scope in several Jesuit establishments simultaneously. The names of both architects are often quoted in connection with the same projects. Combined with the lack of adequate primary sources, this fact makes it difficult to describe the features of their respective oeuvres.

Bernardoni was responsible for the design of the church in Nesvizh (built between 1586 and 1593), one of the first adaptations of the Il Gesù church in Rome (see Figure 1). The adaptation of the original is necessarily limited to the plan of the façade and the introduction of a transept and a dome (the corpus of the building is that of a basilica). The church was endowed by Mikołaj Krzysztof Radziwiłl (1549-1616), who was actively involved in the construction, often interfering in the process. Bernardoni was also responsible for the design of a church in Kalisz (built between 1592 and 1597) in which the disposition of the façade (since remodeled) is concordant with that of Nesvizh. The disposition and the proportions of the interiors are the same in both cases: the two churches were both emporium basilicas. ${ }^{23}$

We face the problem of joint authorship in the case of the Lublin church (built between 1584 and 1604), as well as the ones in Jarosław and Cracow. The Lublin church, substantially remodeled since, was designed jointly by Brizzio and Bernardoni. It was an emporium basilica with a presbytery bracketed between two central chapels with a façade that originally resembled that of Nesvizh in form. The Jarosław church (built between 1582 and 1594) has been confirmed as Brizzio's work. It is a one-aisled building with two chapels forming a pseudo-transept. The proportions of the aisle in the case of Jarosław, Lublin, and the first design for Cracow (built between 1594 and 1605) are identical. We also note that the plans of the churches in Lublin, Nesvizh, and Cracow are based upon an identical module. Without entering into a detailed discussion, we may conclude that the first Jesuit churches in Poland were an attempt to

23 Jerzy Paszenda, "Fundacja prymasa Karnkowskiego dla jezuitów w Kaliszu," and "Kościół Bożego Ciała (pojezuicki) w Nieświeżu," in Paszenda, Budowle, 1:101-38, 279-320. 


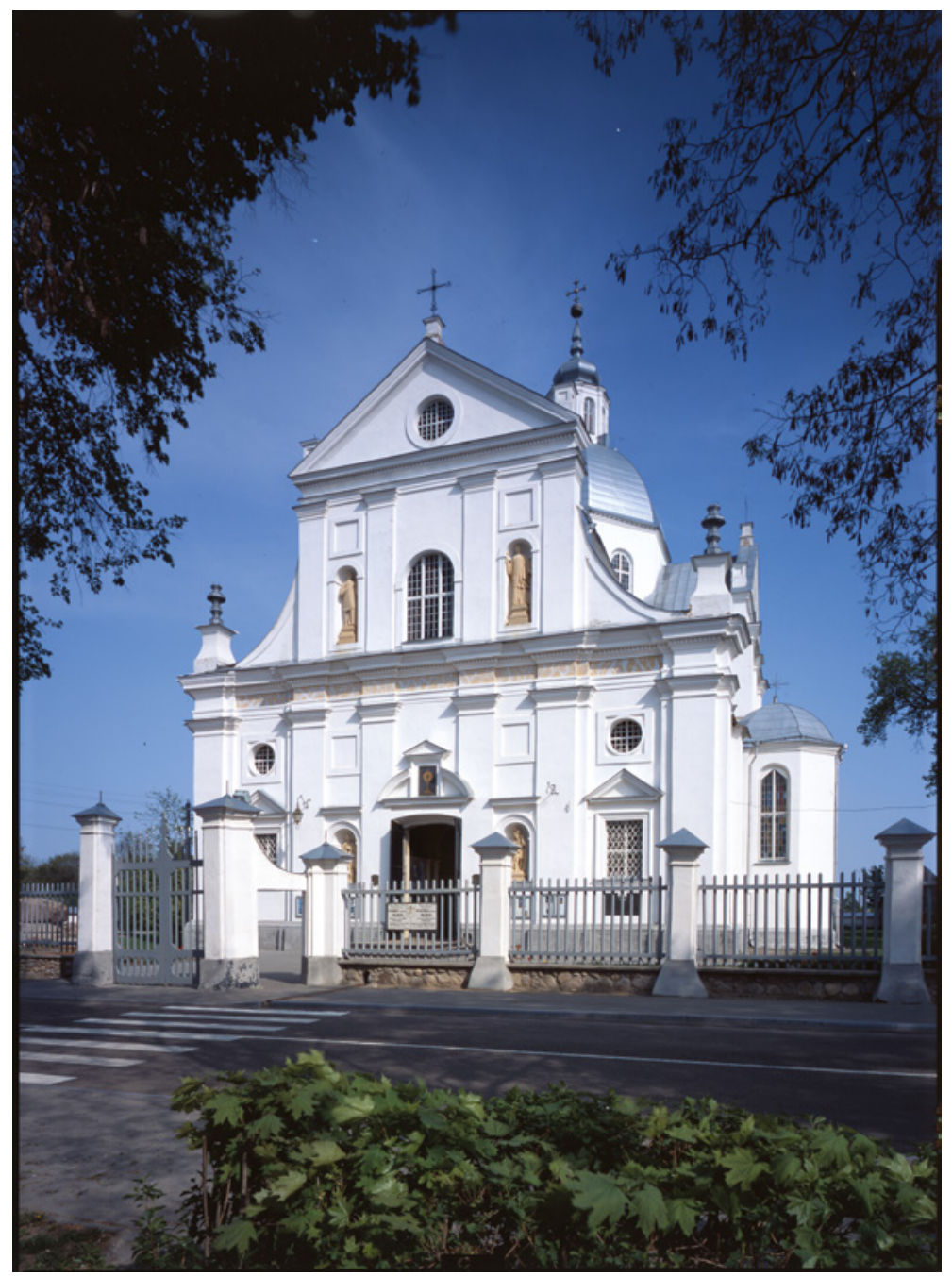

FIGURE 1 Façade of the Jesuit church in Nesvizh (Nieśwież), built between 1586 and 1593, design by Giovanni Maria Bernardoni. PHOTO ANDRZEJ BETLEJ.

create a local blueprint for a church, which was subsequently adjusted according to the rank of the given establishment and to its location. ${ }^{24}$

The later history of the Cracow church (see Figures 2 and 3 ) is extremely interesting. It should be noted that the church was endowed by the king

24 Jerzy Paszenda, "Jarosław, Lublin, Cracow: Wczesne kościoły jezuickie," in Paszenda, Budowle, 3:163-68. 




FIGURE 2 Plan of the Jesuit church in Cracow, built between 1586 and 1593, design by the Jesuit Giuseppe Brizio. 


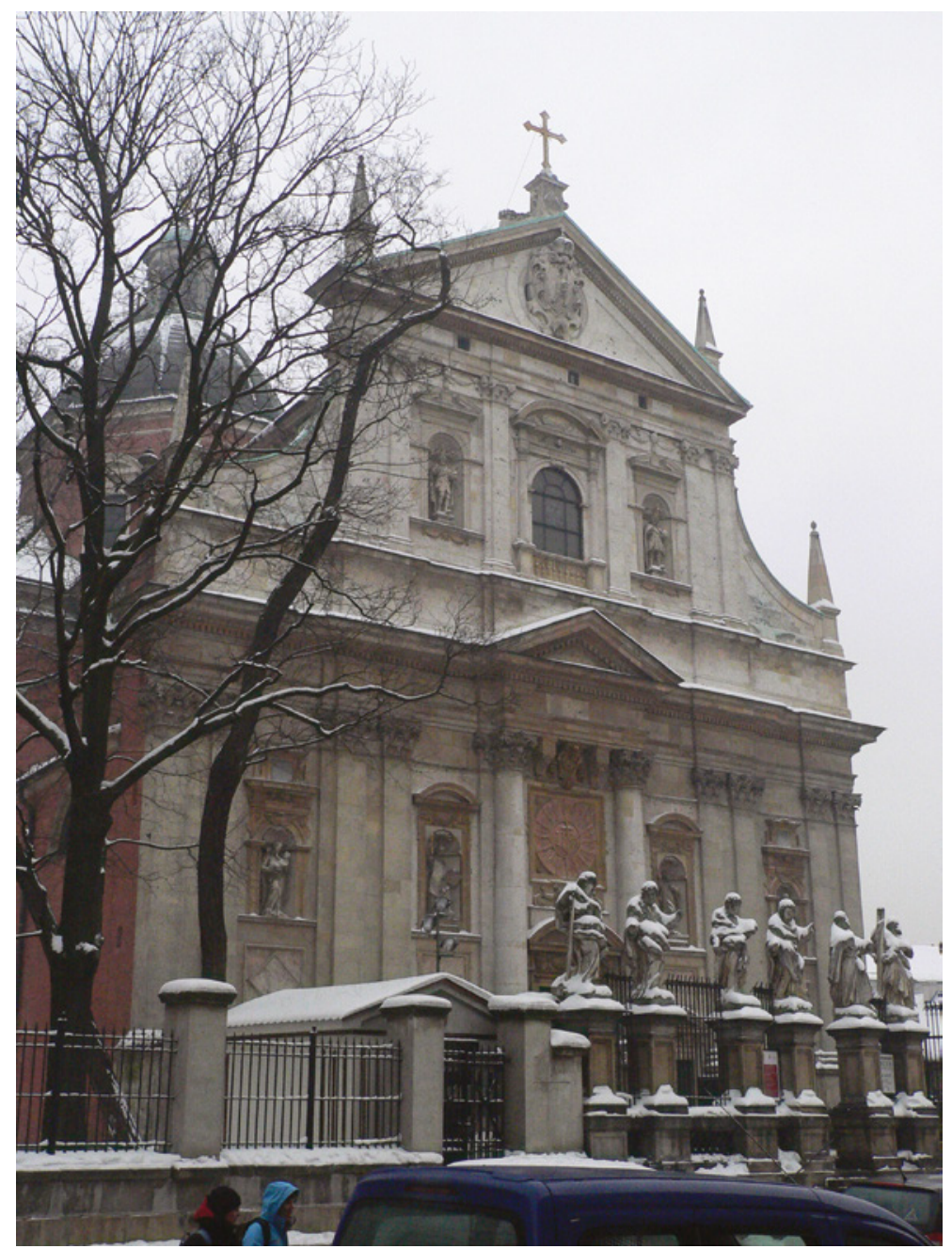

FIGURE 3 Façade of the Jesuit church in Cracow, built between 1586 and 1593 by the Jesuits Giuseppe Brizio, Giovanni Maria Bernardoni and Giovanni Maria Trevano.

PHOTO ANDRZEJ BETLEJ.

Sigismund III Vasa. There was a break in the construction between 1605 and 1610 , and afterwards the process continued with a modified design, planned to conclude around 1620 . It remains a bone of contention to this day when precisely the church received its unique form. The resulting church is a one-aisled building with two side chapels, a homogenous bay structure, a clearly demarcated space beneath the dome, and a decorative façade. The arrangement of the interior, the shape of the dome, and other architectural details bring this 
church close to the works of architecture in Rome, particularly those by Domenico Fontana (1543-1607) and Carlo Maderno (1556-1629). For this reason the church design is attributed to Matteo Castello (c.1560-1632), although other sources mention the architect Giovanni Trevano (d.1643) ${ }^{25}$

The situation is further muddled by the fact that we may adduce other designs by other architects that unquestionably refer to the Cracow church-for instance the drawings of Giacomo Briano of Modena (1589-1649). ${ }^{26} \mathrm{He}$ was perhaps the most interesting artistic personality of all the architects active in the early seventeenth century. Before he entered the Society, he received his education in the field of architecture. Significantly, Briano suggested to his superiors that they use his knowledge not only in the design of new buildings, but also to comment on the work of his most famous architectural contemporaries. Briano was an exceptional artist in the panorama of Polish art, serving as supervisor on all Jesuit construction projects in the region. He was an innovative architect, proposing bold designs; his activity was particularly important as far as the definition of the position of an architect in Poland is concerned. In the sixteenth century, it was common for the architect to be employed at the construction site as one of the builders. However, as the author of the design Briano considered his position exceptional and different from that of a construction worker (even though it gave rise to numerous conflicts).

Briano left behind numerous architectural drawings, some of which are preserved at the Bibliotheque Nationale in Paris, although the bulk of the corpus is at the Getty Research Institute in Los Angeles. ${ }^{27}$ These drawings likely form part of a planned architectural treatise that also was to be a "portfolio" showcasing his spectacular achievements. Detailed descriptions on the projects demonstrate his thorough knowledge and erudition. The artist arrived in Poland in 1616 for the purpose of constructing the church in Lutsk (Euck) (see Figure 4).

25 Małkiewicz, "Kościół śś. Piotra i Pawła," 43-86; Karpowicz, Matteo Castello, 47-73; Małkiewicz, "Trevano czy Castello," 81-108.

26 Adam Małkiewicz, "Jakuba Briana si projekty jezuickiego kolegium w Krakowie," in Festina lente: Prace ofiarowane Andrzejowi Fischingerowi w siedemdziesiata rocznicę urodzin (Stowarzyszenie Historyków Sztuki, 1998), 103-12; Andrzej Betlej, “'Lwowskie’ projekty Giacoma Briano a fasada krakowskiego kościoła śś. Piotra i Pawła," in Magistro et amico amici discipulique: Lechowi Kalinowskiemu w osiemdziesięciolecie urodzin (Wydawnictwo Uniwersytetu Jagiellońskiego, 2002), 271-81.

27 John Bury, Forty-Three Sheets of Architectural Drawings by Giacomo Briano da Modena S.J. (1589-1649): The Society's Architect in Poland and in Northern Italy; A Hitherto Unknown Work of Major Importance for the History of the European Architectural Treatise (Milano: Radaelli, 1985); Andrzej Betlej, "Appunti sui disegni del gesuita Giacomo Briano," Il disegno di architettura 27 (2003): 17-24. 


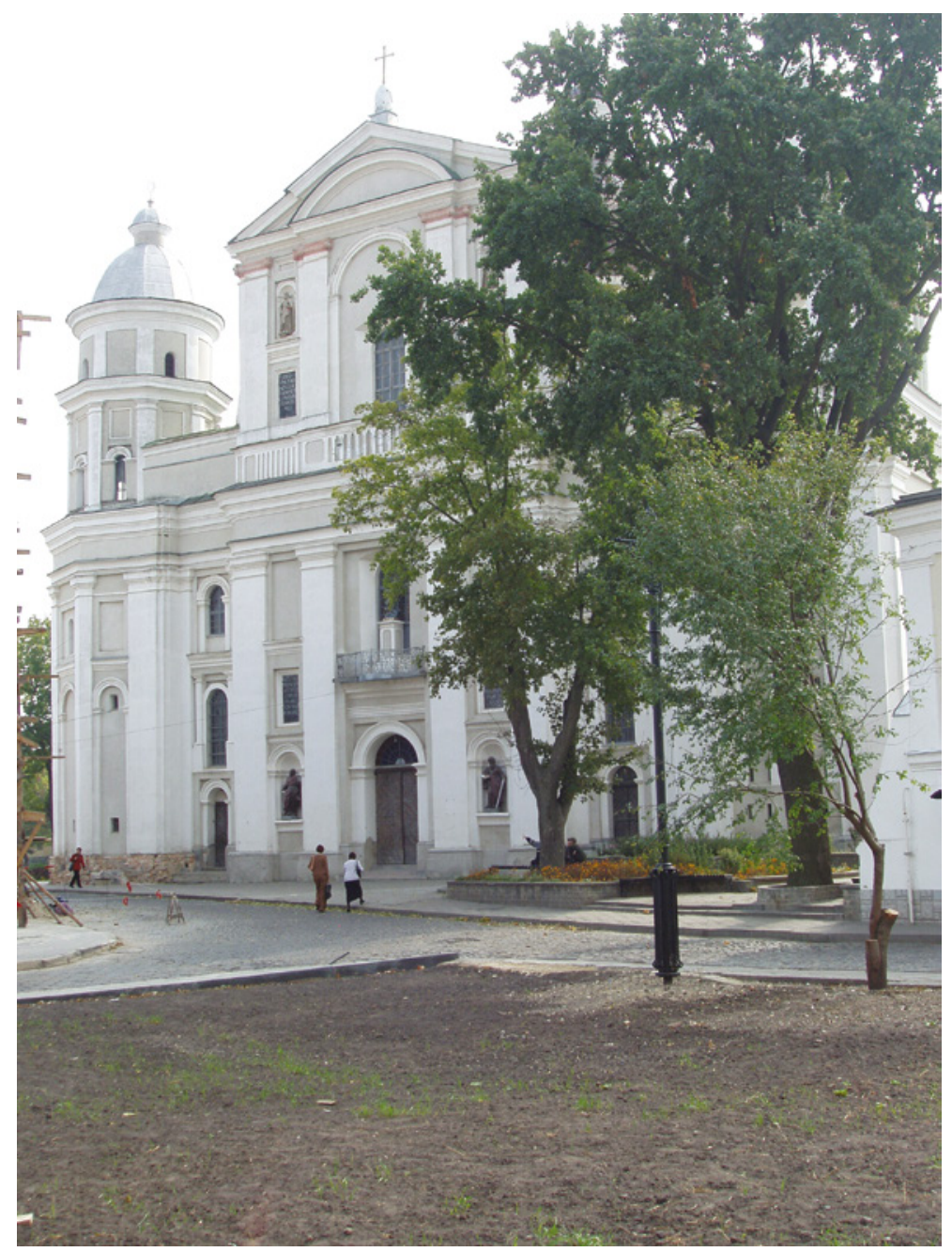

FIGURE 4 Façade of the Jesuit church in Lutsk (Euck), built between 1616 and 1640 , design by the Jesuit Giacomo Briano.

PHOTO ANDRZEJ BETLEJ.

The building was erected upon the central plan of a Greek cross with a dome at the intersection of the aisles-a modified rendition of Rosato Rosati's S. Carlo ai Catinari in Rome. The present shape of the interior is a result of remodeling following the suppression of the Society and dates back to the 1780 s, when the church was turned into the local cathedral. The ornamented façade represents Briano's typical manner of articulation, a homogenous, compact division, using "heavy" classical orders, and the fields between the pilasters filled with 
portals, windows, and panels in sculpted cases. ${ }^{28}$ This creation has a marked similarity to the church in Lviv, constructed simultaneously.

The Lviv church was built between the 1610 s and the $1630 \mathrm{~s}^{29}$ (see Figure 5). An especially large number of designs survive for this building (including

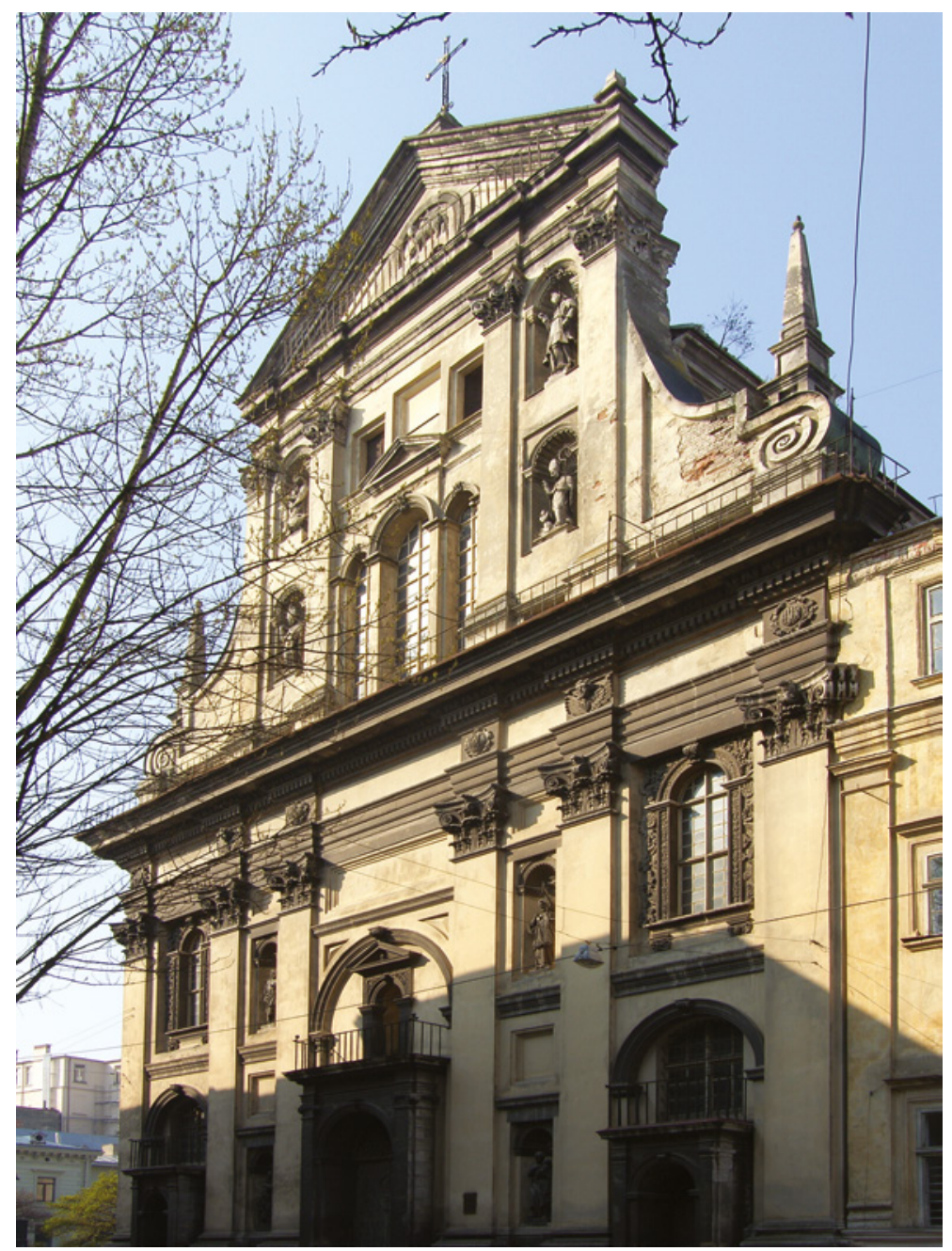

FIGURE 5 Façade of the Jesuit church in Lviv (Lwów), built between 1610 and 1635, design by the Jesuit Giacomo Briano. PHOTO ANDRZEJ BETLEJ.

28 Jerzy Paszenda, "Dzieje budowy kościoła i kolegium jezuitów w Łucku według źródeł jezuickich," in Paszenda, Budowle, 4:149-76.

29 Paszenda, "Kościół jezuitów we Lwowie," 111-40; Betlej, "Kościół p.w. Św. Piotra i Pawła oraz dawne kolegium Ks. Jezuitów," 95-100. 
those in the Graphische Sammlung Albertina and the Getty Research Institute). These designs, as well as the actual finished building, resemble the works of Pellegrino Tibaldi (1527-96) in terms of the interior as well as the central part of the façade. Unfortunately, the dome that Briano designed for the presbytery was never built. ${ }^{30}$ The Jesuit church in Vinnitsa (Winnica), built in the 1630s, was most probably based on the designs for the Lviv church. Here (in the part which has survived to this day) we can also observe Briano's typical arrangement of the façade. Briano was also responsible for the extension of the church in Jarosław (1624), to which he added two chapels and a vestibule. $^{31}$

Briano returned to Poland in 1630 to design the church in Ostroh. He prepared as many as twelve different versions of the design for the benefit of the founder, Anna Chodkiewiczowa (1600-54), which survive in the Bibliothèque Nationale in Paris. The founder aspired to build a magnificent church to hold the funerary monuments of her brothers, who converted from Orthodoxy, and her husband, a military leader who died fighting the Turks. The church was therefore meant as an imposing monument of militant Catholicism and of the Polish-Lithuanian Commonwealth as the guardian of the Faith. Did the construction begin according to Briano's drawings? This is difficult to establish due to the ambiguity of the archival materials. The surviving iconography, however, leads us to suppose that it was largely based upon his conception. A huge church was erected, a three-aisled basilica with a transept, accompanied by an equally monumental college building (see Figure 6). ${ }^{32}$

Particularly interesting among Briano's designs were those intended for Sandomierz, a town located in relative proximity to Cracow, where Jesuits were affiliated with the Gothic church of St. Peter's. The design shows a basilica church with emporia, the nave and the presbytery of equal lengths, and original façades clasped by towers at the corners and at the axis. The forms of the building seem to recall local architectural traditions of the sixteenth century (Briano used the foundations of the Gothic church). ${ }^{33}$ It is worth mentioning

$30 \quad$ Bösel, "Giacomo Briano," 185-88.

31 Jerzy Paszenda, "Kościół św. Jana w Jarosławiu w wiekach Xviı i XVIII," in Paszenda, $B u$ dowle, 1:75-100; Andrzej Betlej, "Kilka uwag na temat projektów rozbudowy kościoła Św. Jana w Jarosławiu autorstwa Giacomo Briano," Modus: Prace z historii sztuki 5 (2004): 22-32.

32 Paszenda "Architektura kolegium jezuitów w Ostrogu," 305-34; Betlej, "Niech przyjdzie tu Witruwiusz," 189-224.

33 About the actual church: Robert Kunkel and Przemysław Mrozowski, "Kościół Św. Piotra w Sandomierzu: Analiza historyczno-architektoniczna," in Sandomierz: Badania 19691973, 2 vols. (Warsaw: Instytut Archeologii i Etnografii PAN, 1996), 144-56; Jerzy Paszenda, "Kościół Świętego Piotra w Sandomierzu," in Paszenda, Budowle, 4:333-56; Jakub Lewicki, 


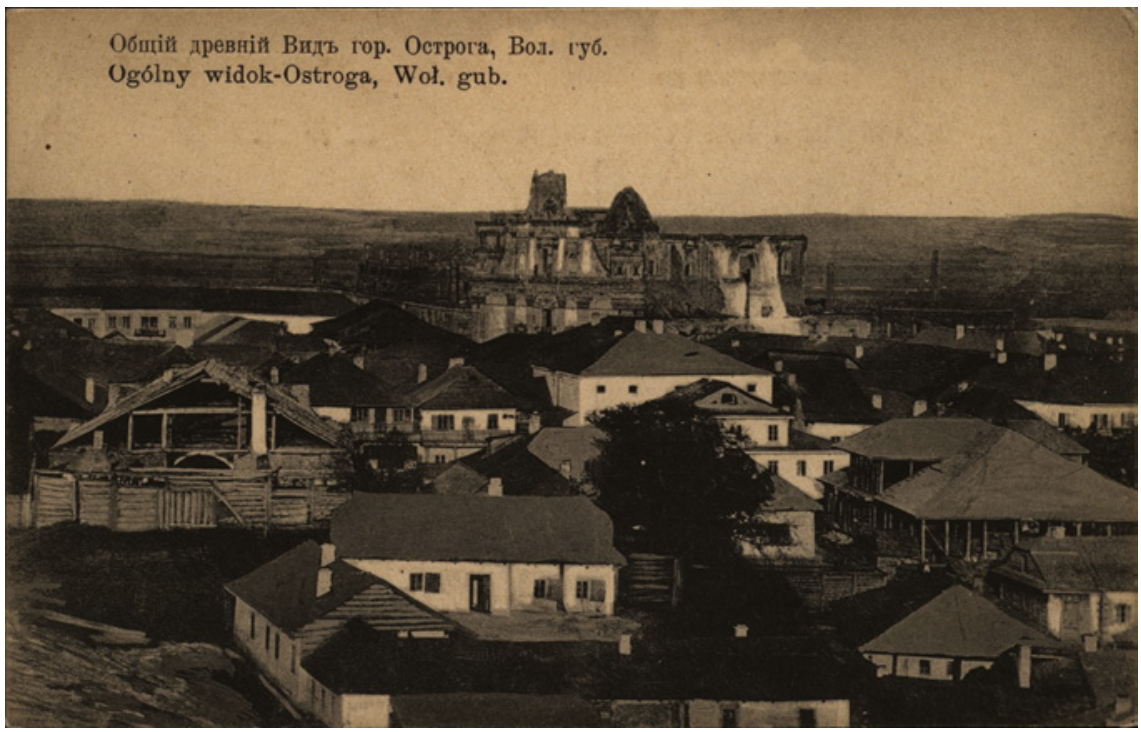

FIGURE 6 General view of the Jesuit church and house in Ostroh (Ostróg), built ca. 1635, design by the Jesuit Giacomo Briano. Nineteenth-century postcard from the collection of Andrzej Betlej.

that the architect was most likely involved in the transformation of the local college where he introduced innovations, like elliptical staircases, hitherto unknown in Polish architecture. Equally interesting, but alas never executed, are Briano's designs for Przemyśl (see Figure 7): the immense college enclosed on two sides, a three-aisled basilica with a transept and a dome. Additionally, Briano planned to attach chapels to the aisle. The façade was supposed to be particularly imposing and representative, a veritable triumphal arch. ${ }^{34}$

Apart from Briano, one more architect should be mentioned: Benedetto Molli (1597-1657), who continued Briano's work on the construction of the Ostroh church. However, it is disputed whether he followed his own design or Briano's. It is certain that the Lutsk college is his conception (only partly executed). The disciples of this first generation of architects included the Jesuits Michał Hinz (1559-1609) and Jan Frankiewicz (1559-1627). The former

"Architektura kościoła pw Św. Piotra w zespole Collegium Gostomianum w Sandomierzu," in Sudomiria 2008-2009 (Sandomierz, 2010), 78-98; about Briano's drawings see also Bösel, "Jesuitenarchitektur," 1330-31.

34 Andrzej Betlej, "Kilka uwag na temat kościoła Jezuitów w Przemyślu w XVII wieku," Roczniki humanistyczne KUL: Historia sztuki 5o (2002): 301-21. 


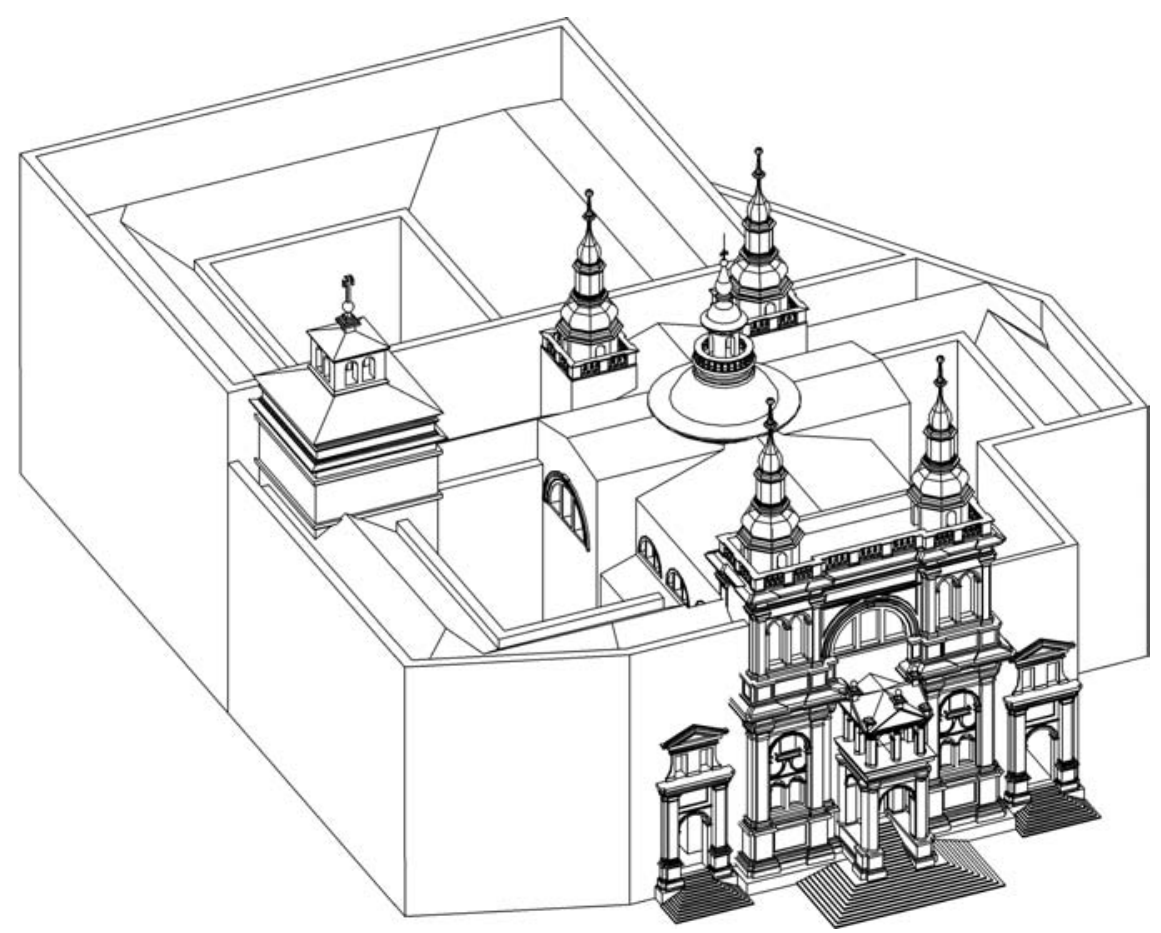

FIGURE 7 Reconstruction of the Jesuit church and cloister in Przemyśl after the designs of the Jesuit Giacomo Briano. Drawn by Andrzej Betlej.

is responsible for the college in Lublin, ${ }^{35}$ while the latter is the author of St. Kazimierz church in Vilnius.

The construction of the church of St. Kazimierz (Casimir) began in 1604 (Figure 8). The foundation coincided with St. Kazimierz's proclamation as the patron saint of Lithuania and the public announcement of the Brzesko Union, a visible sign of the Catholic Church's triumph in the eastern lands. The completion of the construction coincided with the celebrations of the anniversary of the victory against the Russian Empire (the conquest of Moscow in 1612). Frankiewicz is the author of the design, while the proportions and shape of the church are modelled upon the plans of the churches in Cracow and Lublin, with towers added. Due to its denomination, the church always enjoyed the

35 Jerzy Paszenda, "Chronologia budowy zespołu gmachów jezuickich w Lublinie," "Lubelskie projekty Michała Hintza i Jakuba Briano," in Paszenda, Budowle, 1:139-208. 


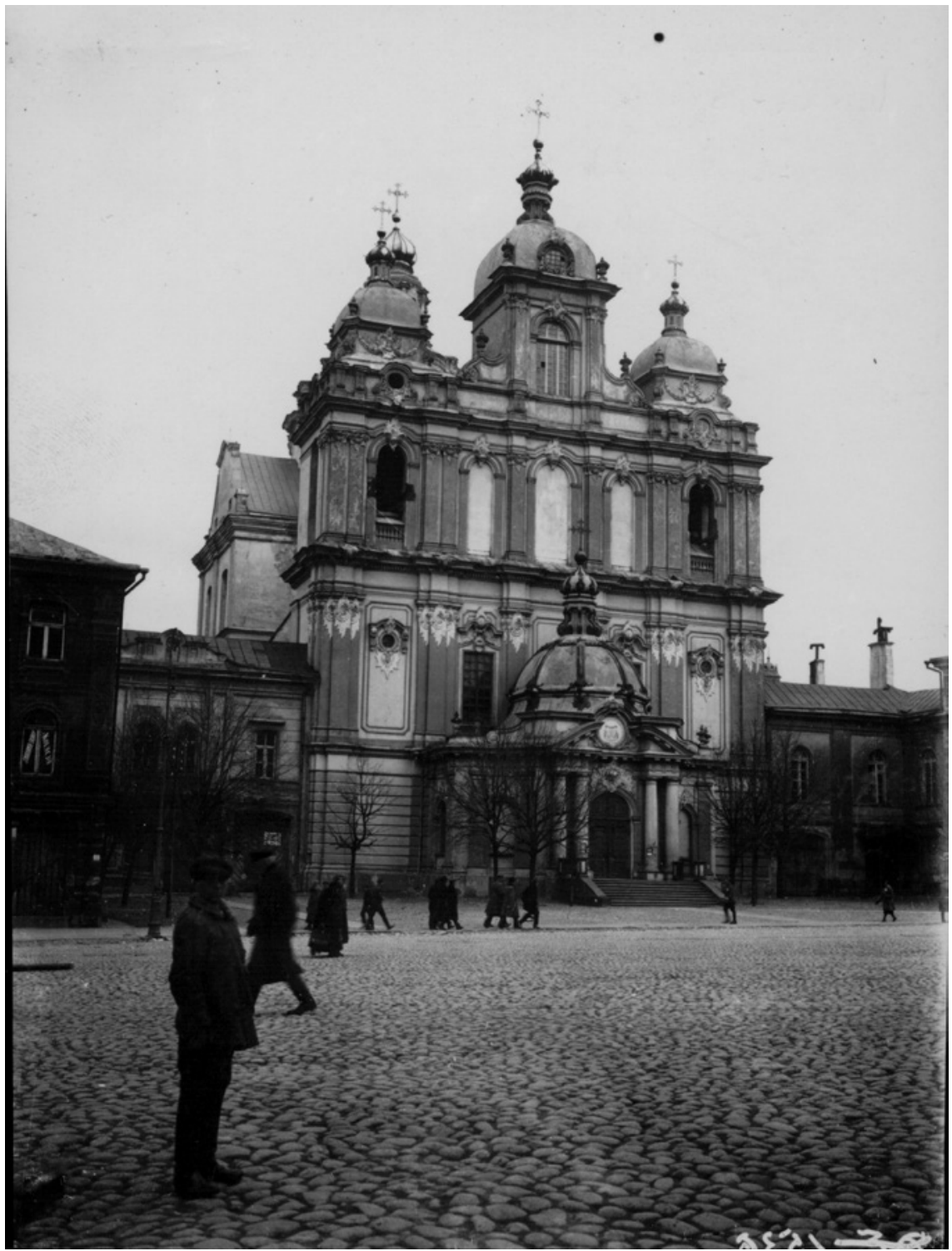

FIGURE 8 Façade of the Jesuit church (St. Casimir) in Vilnius (Wilno), built between 1604 and 1618 by the Jesuit Jan Frankiewicz.

PHOTO FROM THE COLLECTION OF INSTITUTE OF ART HISTORY, JAGIELLONIAN UNIVERSITY. 


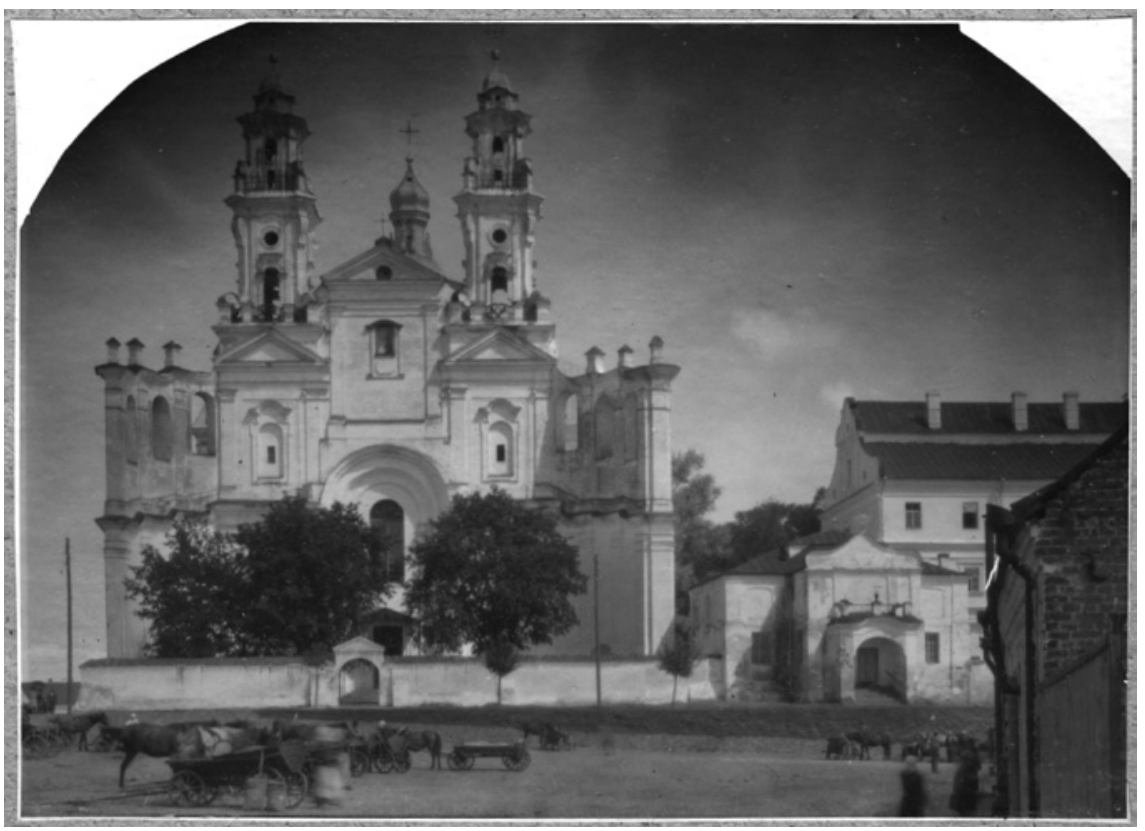

FIGURE 9 Façade of the Jesuit church in Pinsk(Pińsk), built between 1636 and 1647, façade rebuilt between 1747 and 1758 .

PHOTO FROM THE COLLECTION OF INSTITUTE OF ART HISTORY, JAGIELLONIAN UNIVERSITY.

patronage of the most illustrious representatives of the Lithuanian magnates; it also served as an informal mausoleum of the Vasa dynasty. ${ }^{36}$

The construction of the exceedingly heterogeneous church in Pinsk (Pińsk) had begun before the mid-seventeenth century (built between 1636 and 1647, no longer extant [Figure 9]). This amazing creation was a result of several remodeling projects. Initially designed as a basilica church, towards the end of the seventeenth century it was turned into a hall, with a tower attached to it at a later date; later still, a transept and a presbytery were added. The façade, quasi-theatrical, in the shape we know from surviving photographs, was constructed in the mid-eighteenth century, and the dome was added in the nineteenth century when the building was taken over by the Orthodox Church. ${ }^{37}$

In the panorama of Jesuit architecture, the Warsaw (Warszawa) church (built between 1609 and 1624) stands out. It is a strikingly slender building,

36 Baranowski, “Rola kościołów jezuickich,” 286-87; Jerzy Paszenda, “Kościół p.w. św. Kazimierza w Wilnie," in Paszenda, Budowle, 4:427-6o.

37 Paszenda, “Kościół i kolegium jezuitów w Pińsku," in Paszenda, Budowle, 4:213-50. 
with a mannerist façade, an original presbytery with a domed apse, and an adjoining tower. The design has been attributed to two architects: Jakub Balin (d.1623) and the aforementioned Jesuit Jan Frankiewicz. ${ }^{38}$ The disposition of the façade is archaic, but the interior is very unusual and suggests the participation of an Italian architect, perhaps Briano.

To sum up the first stage of the development of Jesuit architecture, we should conclude that by the mid-seventeenth century, twenty-one churches were constructed, accompanied by fifteen college buildings. Unfortunately, this dynamic development of the Society was slowed down by war, as mentioned above. It was not until the second half of the seventeenth century, particularly in the 1670 s, that the second architectural "boom" occurred. That period, during which more than twenty churches and ten colleges were built, is often referred to as the "re-Catholicization" of the Polish-Lithuanian Commonwealth. Significant Jesuit establishments were built in Święta Lipka, Poznań, Krasnystaw, Przemyśl, and Hrodna (Grodno), to name but a few. These buildings are situated within the mode of traditional architecture, following blueprints that date back to the first half of the century, although we also note some outstanding works evoking major accomplishments of Western European architecture.

Within the aforementioned traditional strand of Jesuit architecture, we can place, for instance, the church in Przemyśl, completed in 1671 and most probably the work of Jakub (Giacomo) Solari (1559-1609); the church in Krasnystaw (erected between 1697 and 1715 according to the design of the Jesuit Jan Ignacy Delamars [1656-1719]);39 and the new church in Jarosław (called "in the Field," constructed between 1698 and 1709, with a dynamic screen façade on the side of the presbytery, fitted in the eighteenth century). ${ }^{40} \mathrm{~A}$ special place in this architectural panorama is held by the church in Święta Lipka (Figure 10) in the Warmia region, built between 1688 and 1693. The church is a pilgrimage site. Surrounded with a cloister, it has a decorative façade with mounted columns (which have precedents in earlier Polish architecture, including the church in Tarłów and ss. Peter and Paul's in Vilnius). ${ }^{41}$ The church at Hrodna, built between 1678 and $1705,{ }^{42}$ repeats the dominant scheme of a basilica, present in

38 Miłobędzki, Architektura polska, 121; Mariusz Karpowicz, Artisti Ticinesi in Polonia nella prima metà del '6oo (Ticino: Ticino Management SA, 2002), 83-85; Jerzy Paszenda, "Zabudowania jezuickie na Starym Mieście w Warszawie," in Paszenda, Budowle, 4:427-6o.

39 Jerzy Paszenda, "Lubelska rodzina Delamars," in Studia nad sztuka renesansu i baroku, ed. Jerzy Lileyko, 4 vols. (Lublin: Towarzystwo Naukowe KUL, 2000), 105-19.

Jakub Sito, "O dwóch koncepcjach 'ślepej' fasady kościoła jezuitów w Jarosławiu," in Między Padwa a Zamościem: Studia z historii sztuki i kultury nowożytnej ofiarowane Profesorowi Jerzemu Kowalczykowi (Warsaw: Instytut Sztuki PAN, 1993), 289-301.

41 Jerzy Paszenda, Święta Lipka: Monografia (Cracow: WAM, 2008).

42 Jerzy Paszenda, "Kościół pojezuicki (farny) w Grodnie," in Paszenda, Budowle, 2:37-78. 




FIGURE 10 General view of the Jesuit church in Święta Lipka, built between 1688 and 1693. PHOTO ANDRZEJ BETLEJ.

Jesuit architecture since the beginning of the century. The façade is a more robust version of the one found in the Vilnius church (Figure 11). However, the reception of the church is largely informed by the main altar (Figure 12), which fills the whole of the apse (dating to 1736 , the work of Johann Christian Schmidt [c.1701-59]).43

This period brought also the influence of the Italian high baroque to Jesuit architecture. Towards the end of the seventeenth century, the architecture of Polish (and Jesuit) church interiors began to exhibit combined architectural, sculpted, and painted motifs similar to the works of Gian Lorenzo Bernini (1598-1680). In order to impart dynamic qualities to the space of church interiors, architects introduced free-standing columns, like those in the church in Poznań, built between 1671 and 1701 by the Jesuit Bartłomiej Nataniel Wąsowski (1617-87). This coulisse-like, stenographic composition recalls structures by

43 Mariusz Smoliński, Rzeźbiarz Jan Chrystian Schmidt: Rola Warmii jako prowincji artystycznej w XVIII wieku (Olsztyn: Ośrodek Badań Naukowych im. W. Kętrzyńskiego, 2006), 26-31. 


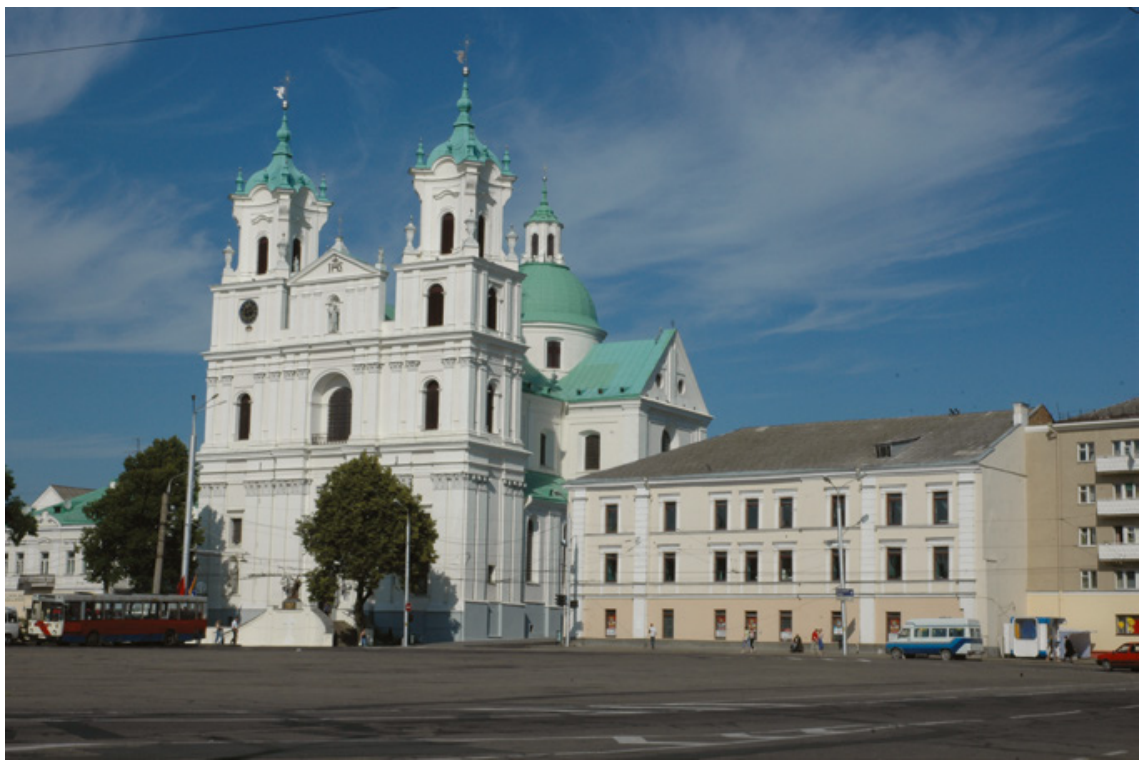

FIGURE 11 General view of the Jesuit church in Hrodna (Grodno), built between 1678 and 1705. PHOTO ANDRZEJ BETLEJ.

Baldassare Longhena (1598-1682), Andrea Pozzo (1642-1709), and representatives of the Bibiena family (Figure 13). Wąsowski was an artist of thorough and versatile education. He completed his architectural studies prior to entering the Society (unfortunately we do not know where and with whom he received this training), and he complemented it with an art-themed journey around Europe, which he recorded in writing and in sketches. ${ }^{44}$ Moreover, Wąsowski was the author of a contemporary textbook of architecture, entitled Callitectonicorum, seu de pulchro architecturae sacrae et civilis compendio, published in 1678, in which he stressed the aesthetic values of ecclesiastical architecture. Beyond this, the book was a compilation of works by Sebastiano Serlio (1475-1554), Jacopo Barozzi Vignola (1507-73), Andrea Palladio (15088o), and Vincenzo Scamozzi (1548-1616). ${ }^{45}$ Apart from Wąsowski, we should

44 Adam Małkiewicz, "Bartlomeo Nataniele Wąsowski e l'architettura italiana: Un viaggio italiano di Wąsowski nel 1655 e la sua attività trattatista e architetto," in Viaggio in Italia e viaggio in Polonia (Cracow: Wydawnictwo Uniwersytetu Jagiellońskiego, 1994), 129-43.

45 Baranowski, Barttomiej Nataniel, 150-169; Miłobędzki, Architektura polska, 413-24; Adam Małkiewicz, "Udział Bartłomieja Nataniela Wąsowskiego w budowie kościoła i kolegium jezuitów (obecnie farnego) w Poznaniu," in Adam Małkiewicz, Theoria et Praxis: Studia z dziejów sztuki nowożytnej i jej teorii (Cracow: Universitas, 2000), 303-36; Jerzy Paszenda, "Bartłomieja Wąsowskiego własnoręczne projekty dla Poznania, Jarosławia i Lwowa," Biuletyn historii sztuki 49 (1987): 251-25. 


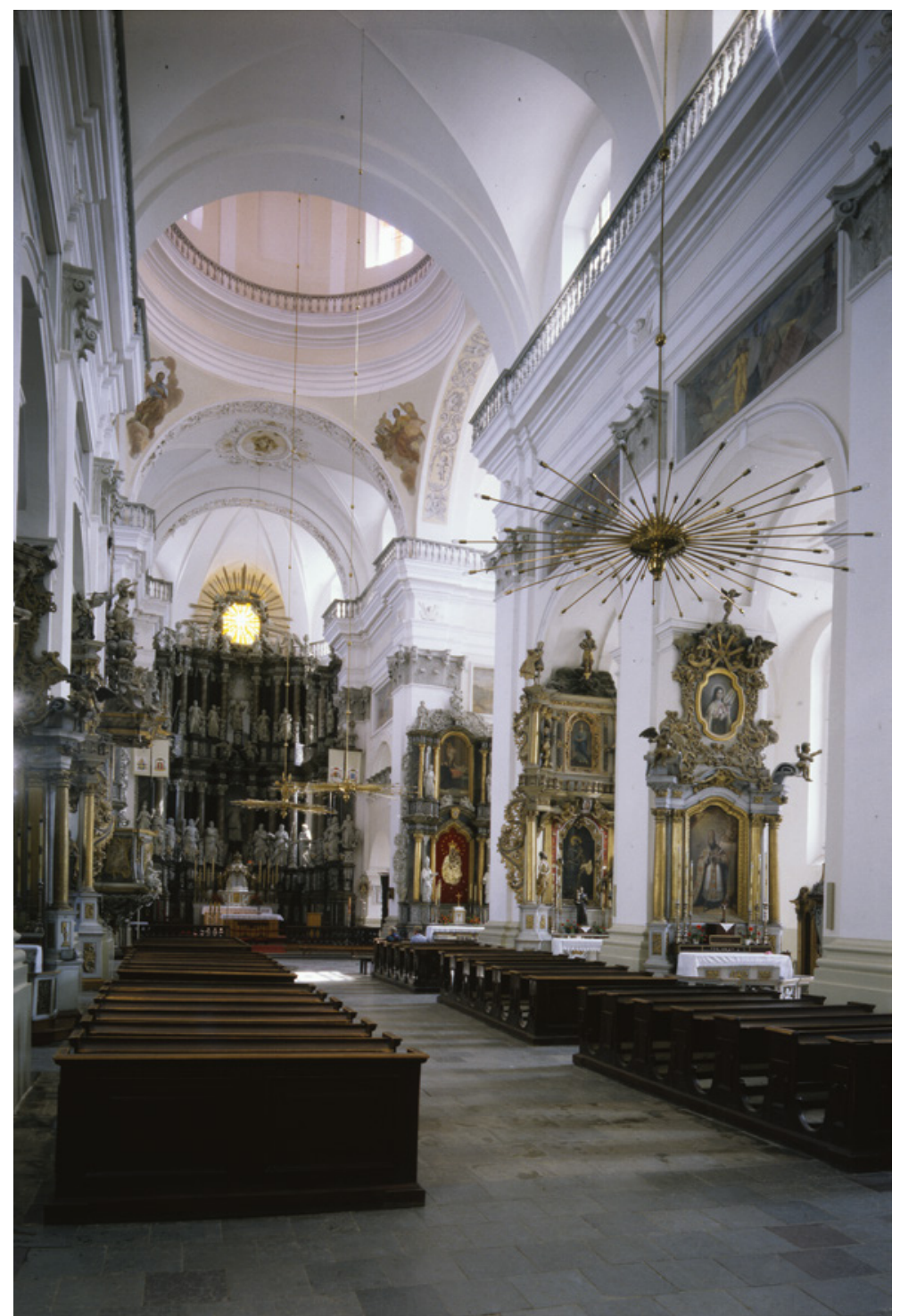

FIGURE 12 Interior of the Jesuit church in Hrodna (Grodno), main altar built in 1736 by Johann Christian Schmidt.

PHOTO ANDRZEJ BETLEJ.

note another illustrious Jesuit personality: Stanisław Solski (1622-1701), who earned his place in the history of architecture as an excellent mathematician and architectural advisor to Cracow's bishop, Jan Małachowski (1623-99). He was the author of the work entitled Architekt polski (The Polish architect), 




FIGURE 13 Interior of the Jesuit church in Poznań, built between 1671 and 1701 by the Jesuit Barttomiej Nataniel Wasowski. PHOTO ANDRZEJ BETLEJ.

published in 1690,46 and is linked to the unrealized design (1694) for the Lazarites' church in Cracow, clearly influenced by the Jesuit Andrea Pozzo's (1642-1709) work. $^{47}$

46 Adam Małkiewicz, Teoria architektury w nowożytnym piśmiennictwie polskim (Cracow: Wydawnictwo Uniwersytetu Jagiellońskiego, 1976), 170-81.

47 Adam Małkiewicz, "Niezrealizowany projekt krakowskiego kościoła Misjonarzy na Stradomiu i jego domniemany autor: Przyczynek do działalności architektów dyletantów w 
The beginning of the eighteenth century was, generally speaking, an adverse time for the development of architecture in Poland. The Northern Wars, followed by the civil war within the Commonwealth, either slowed down or put a stop to many endowment projects. Worthy of note is an important artistic phenomenon that started in the second quarter of the eighteenth century: large-scale transformations of the interiors and refurbishings of the internal decoration in buildings erected in the previous century (as was the case for the churches in Ostroh, Lviv, Nesvizh, and Lublin [Figures 14 and 15]).

Another vital problem was instruction in architecture within the Jesuit order. It was Father Faustyn Grodzicki $(1710-87)$ who had rendered the greatest service in this regard, having instituted a mathematical college in Krasnystaw in 1728 (later transferred to Lviv). In addition to those active in Lviv, we should mention several other members of the Society: Gabriel Lenkiewicz (1722-98), who was trained in Rome and taught architecture in the college at Polotsk (Połock), as well as Franciszek Kareu (1731-1802), Gabriel Gruber (1740-1805), Józef Połoński (1744-1808), Tomasz Żebrowski (1714-58), and Tomasz Poczobutt-Odlanicki (1728-1810) - all of whom were trained in Prague and taught in Vilnius. The Jesuit Jan Rossignol (1726-1817) and Carlo Sampani (d.1783) also taught at Vilnius. Since the 176os, courses in architecture had been taught in the Warsaw Collegium Nobilium and in Poznań.

From the 1730s, we again notice a substantial increase in the number of construction projects carried out by the Society. At that time, as many as thirty-seven churches and colleges were built. Interestingly enough, in that period, virtually every province (or every section of the Polish-Lithuanian Commonwealth) had its own, informal chief architect or architects. The Jesuits Franciszek Koźmiński (1702-68) and Józef Feliks Rogaliński (1728-1802) were active in Greater Poland (Wielkopolska); Paweł Giżycki (1692-1762) and Faustyn Grodzicki (1710-87) in Russian territory; Tomasz Żebrowski (1714-58) in the Grand Duchy of Lithuania; and Józef Karsznicki (1719-1805) in Lesser Poland (Małopolska). In the second half of the eighteenth century, a sort of schema for conducting construction works developed. At that time, a group of well-trained building-site supervisors had emerged who oversaw successive

Krakowie w epoce baroku," Rocznik krakowski 75 (2009), 71-82; Richard Bösel, "L'impegno didattico: L'accademia di Andrea Pozzo al Collegio Romano," in Mirabibli disinganni: Andrea Pozzo (Trento 1642-Vienna 17o9); Pittore e architetto gesuita, ed. Richard Bösel and Lydia Salviucci Insolera (Rome: Artemide, 2010), 204; Piotr Krasny, “Kościół Misjonarzy na Stradomiu czyli krakowski sequel rzymskiej lekcji pokory dla Berniniego," in Initium sapientiae humilitas: Studia ofiarowane Jakubowi Pokorze z okazji 7o. urodzin (Warsaw: Uniwersytet Kardynała Stefana Wyszyńskiego, 2015), 510-25. 


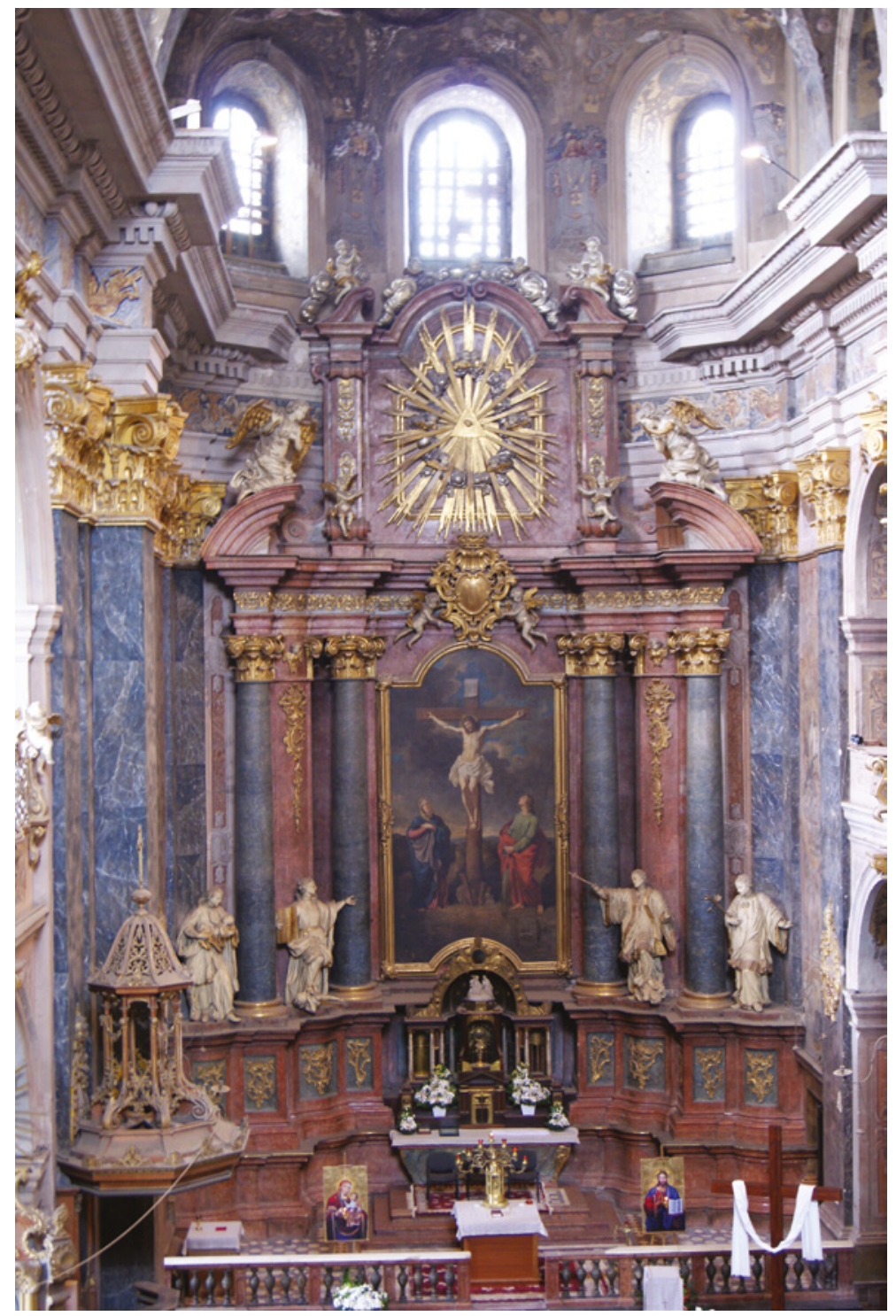

FIGURE 14 Main altar of the Jesuit church in Lviv (Lwów), built 1744. PHOTO ANDRZEJ BETLEJ.

projects and who were tossed from one place to another, depending on where a construction or refurbishment of a church was taking place at a given moment. In this regard, the name of the Jesuit Jan Zelner (1689-1754) should be mentioned, as well as those of the Jesuits Michał Sobolewski (1731-84) and Tomasz Siekierzyński (1720-77). 


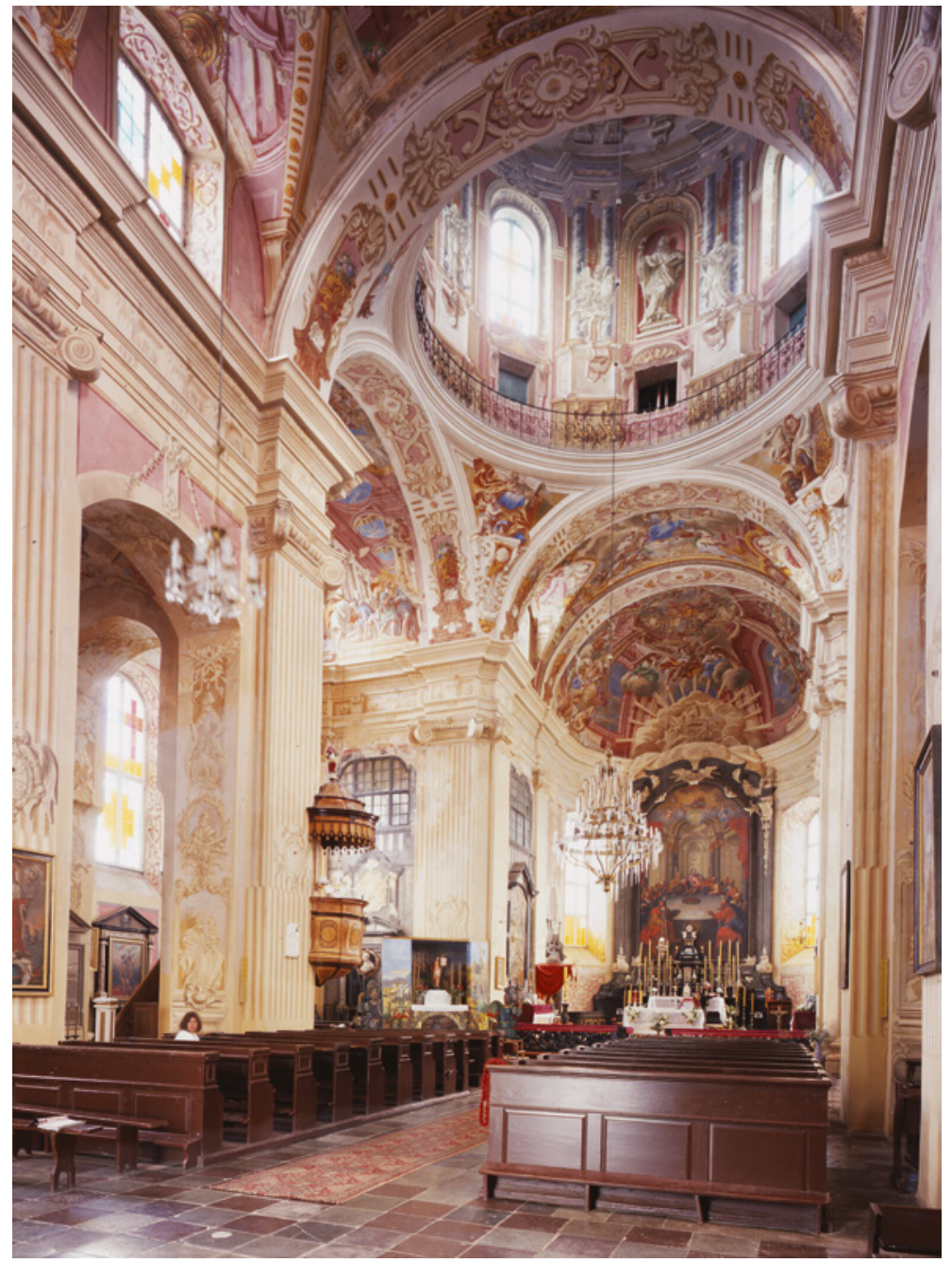

FIGURE 15 Interior of the Jesuit church in Nesvizh (Nieśwież). PHOTO ANDRZEJ BETLEJ.

By far the most interesting of the group was Giżycki, ${ }^{48}$ who had been educated outside the Society, most probably in the circle of Kacper Bażanka (c.16801726), a graduate of the Roman Academia di San Luca. At any rate, in the work of this Jesuit we find the same eclectic manner of composing the artwork and a predilection for imitating Italian models (naturally), particularly those of Pozzo. Giżycki was a versatile artist (we might dub him an "architect-cum-stage

48 Betlej, Ksiadz Pawet, 45 . 
designer") as he not only designed churches and colleges, but was also a renowned master of artistic catafalque decorations (so-called castra doloris). What is more, Giżycki did not just work for the Society. It is quite telling that he was used, rather like a court architect, by the founders of Jesuit works and on other endowments, including designs for the Dominicans in Chortoryisk (Czartorysk) and a Basilian Orthodox church in Piddubne (Poddębce), which was another instance of his borrowing from Pozzo's models. ${ }^{49}$

His capolavoro is the church and college in Kremenets (Krzemieniec [Figure 16]), founded by the Wiśniowiecki family in the 1730 s and completed in the $1760 s$. The first designs for the building were developed by Paolo Antonio Fontana (hence the "wavy" façade, exhibiting the influence of Filippo Juvara [1676-1736]); however, the decorative divisions and details, and the rendition of the trefoil plan, these are the input of Giżycki. Another significant work of Giżycki's is the church at Yuravichy (Jurewicze, built between 1746 and 1756), where the disposition scheme for the façade resembles the one in Kremenets, with further similarities to be found in the arrangement of wall surfaces (with

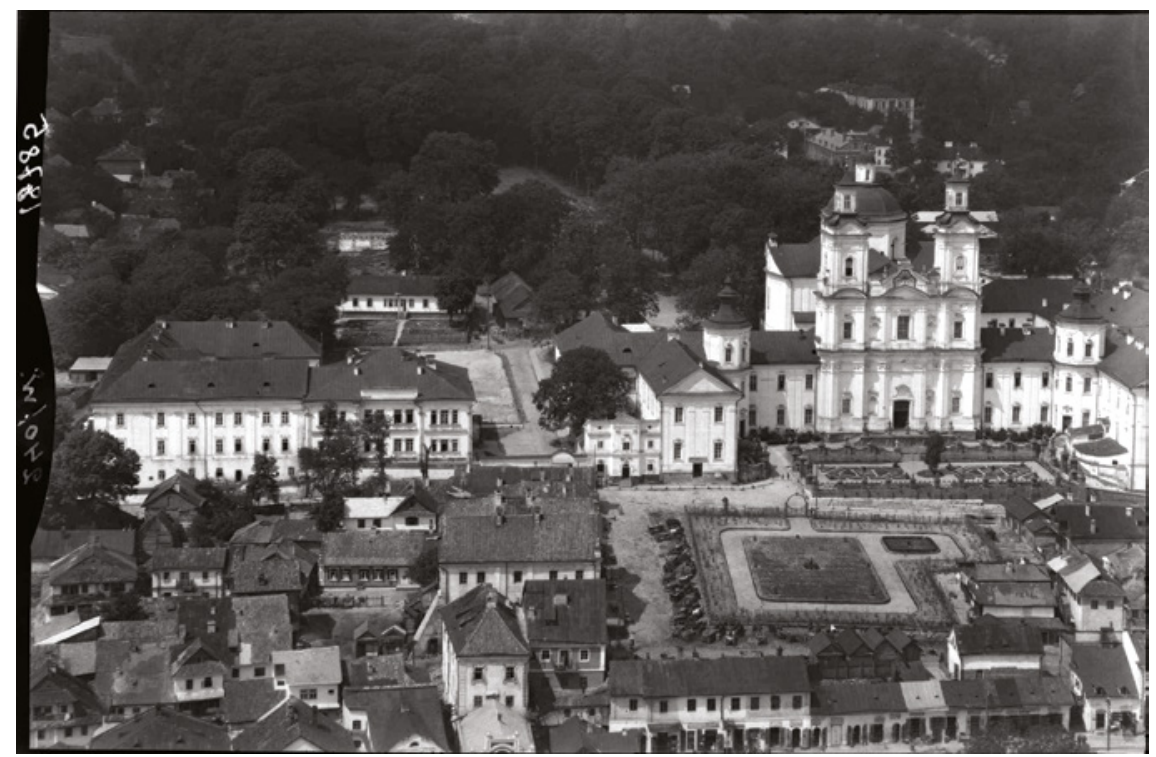

FIGURE 16 General view of the Jesuit church in Kremenets'(Krzemieniec), built between 1730 and 1760 by the Jesuit Pawet Gizycki. Archival photo (pre-1945) from the Collection of the Institute of Art History, Jagiellonian University.

49 Józef Skrabski, Paolo Fontana: Nadworny architekt Sanguszków (Tarnów: Muzeum Okręgowe w Tarnowie, 2007), 269. 
manifold, superimposed framings). The church used to have a main altarpiece based on Pozzo's designs for the church of Sant'Ignazio in Rome. In addition to these works, Giżycki probably designed the churches in Ivano-Frankivsk (Stanisławów, built between $175^{2}$ and 1763 ) and Ovruch (Owrucz, built between 1753 and 1769). These buildings are more archaic, or conservative, in terms of their plan, but they were equipped with decorative façades of typical ornamental details, in the Borromini tradition.

Completing the panorama, there are several lesser buildings that exhibit close associations with Italian solutions. An interesting example of such an adaptation was the church in Pavlivka (Poryck, built between $175^{1}$ and 1763), the façade of which repeated the composition of the Oratorio del Quirico in Pavia, the work of Giovanni Veneroni. ${ }^{50}$ The church in Vlodymyr-Volynsky (Włodzimierz Wołyński, built between 1755 and 1766) is also noteworthy, with its quasi-theatrical, stage-like arrangement of the interior, clearly deriving from Roman models at the turn of the seventeenth and eighteenth centuries (we might point out Gregorio Castrichini's [1654-1737] projects for the St. Apollinare church at the Collegium Germanicum in Rome, or some designs of Nicolo Salvi's [1697-1751]); the design of the interior is modelled after the nave of San Fedele in Milan. ${ }^{51}$

The late-baroque stylistic modus is also represented in churches in the Grand Duchy of Lithuania through the 1730s: Minsk (built between 1700 and 1710), Mstislavl (Mścisław, built between 1730 and 1748), Faschevka (Faszczówka, built between 1738 and 1754), Orsha (Orsza, built between 1741 and 1765)the latter three attributed to Józef Fontana (1716-c.1772)—Mogilev (Mohylew, built between 1719 and 1725), or Vitebsk (Witebsk, built between 1712 and 1731, probably by Jan Pensa [1689-1754] of Vilnius). ${ }^{52}$

5o Betlej, Ksiądz Pawet, 101-15; 117-21; 138-49, 153-57; see also Betlej, "Dawny kościół p.w. Niepokalanego Poczęcia Najśw. Panny Marii i Św. Alojzego Gonzagi (obecnie cerkiew katedralna p.w. Zmartwychwstania Pańskiego) oraz kolegium jezuitów w Stanisławowie," in Materiaty do dziejów sztuki sakralnej na ziemiach wschodnich dawnej Rzeczypospolitej. Kościoty i klasztory rzymskokatolickie dawnego województwa ruskiego, ed. Jan Ostrowski, vol. 14 (Cracow: Międzynarodowe Centrum Kultury, 2006), 359-68.

$5^{1} \quad$ Aleksander Stankiewicz, "Pojezuicki kościół pod wezwaniem Rozesłania Apostołów we Włodzimierzu Wołyńskim a wpływy traktatu architektonicznego Andrei Pozza na architekturę sakralną XVIII-wiecznej Rzeczypospolitej," in Prolegomena: Materiaty studentów i doktorantów historii sztuki, ed. Andrzej Betlej (Cracow: Oficyna Wydawnicza Text, 2013), 63-83.

$5^{2}$ Wojciech Boberski, "Dzieje fary w Witebsku i jej architektoniczne przemiany," in $S z$ tuka kresów wschodnich, ed. Andrzej Betlej and Piotr Krasny, vol. 4 (Cracow: Oficyna Wydawnicza Text, 1998), 43. 
In the eighteenth century, the architecture of Jesuit churches in the southeastern lands of the Commonwealth stylistically evoked mostly Roman models, although an element of south German (Bavarian) architecture is also important. It is particularly visible in works erected after 1738 in the Grand Duchy of Lithuania - notably in Vilnius, in the churches of Św.Jan (Saint John) and Św. Kazimierz (Saint Casimir), with their exceptional groups of altars. While the concept of a grand, theatrical, stucco altar with superimposed, fluid elements may be derived from the works of Pozzo (quarantore designs), artistically it draws directly from Augsburg patterns that gained publicity through ornamental etchings (for example by Johann Michael Leuchte [d.1759] and Franz Xaver Habermann [1721-96]).

One of the most perfect examples of this type of quasi-theatrical arrangement (Figure 17) can be found in the remodeled Gothic church of St. John in Vilnius (built between 1748 and 1762). It was designed by probably the most outstanding representative of the Vilnius baroque-Johann Christoph Glaubitz (c.170o-67), executed by the Jesuits Michael Schick (1714-46) and Jakob Grimm (1709-90). The latter architect also designed the new façade for the church (probably built between in 1738 and 1745 ; Figure 18), this time very clearly inspired by Guarino Guarini's (1624-83) projects for the church of San Filippo Neri in Turin. ${ }^{53} \mathrm{He}$ is also responsible for the dome and the altars in the church of St. Casimir. Our attention is drawn to the rendering of the dome, which brings associations with some Austrian buildings, such as the shape of the towers in St. Pölten or the church in Herzogenburg. ${ }^{4}$

Another important Jesuit architect in Lithuania was the aforementioned Tomasz Żebrowski, who authored-among other works-the astronomical observatory in Vilnius. He was involved in the construction of the dome above Św. Kazimierz's church, and the churches in Babruysk (Bobrujsk, built between 1732 and 1747) and Ilukste (Iłłukszta) in Polish Livonia (now in Latvia), the latter constructed in two phases: the first between 1754 and 1758 , the second between 1761 and $1769 .{ }^{55}$

Other churches in the Grand Duchy of Lithuania consistently replicate models from the so-called "Vilnius rococo." The first in this group is the church in Daugavpils (Dyneburg; built between 1737 and 1746, towers built between

53 Jerzy Kowalczyk, "Guarino Guarini a późnobarokowa architektura w Polsce i na Litwie," Kwartalnik architektury i urbanistyki 42 (1997): 181.

54 Jerzy Kowalczyk, "Późnobarokowa architektura Wilna i jej europejskie związki," Biuletyn historii sztuki 55 (1993): 169-67.

55 Vladas Zubovas, Tomas Žebrauskas ir jo mokiniai (Vilnius: Mokslas, 1986); Vladas Zubovas, “Działalność architektoniczna Tomasza Żebrowskiego," Lituano-Slavica Posnaniensia: Studia historiae artium 5 (1991): 139-70. 


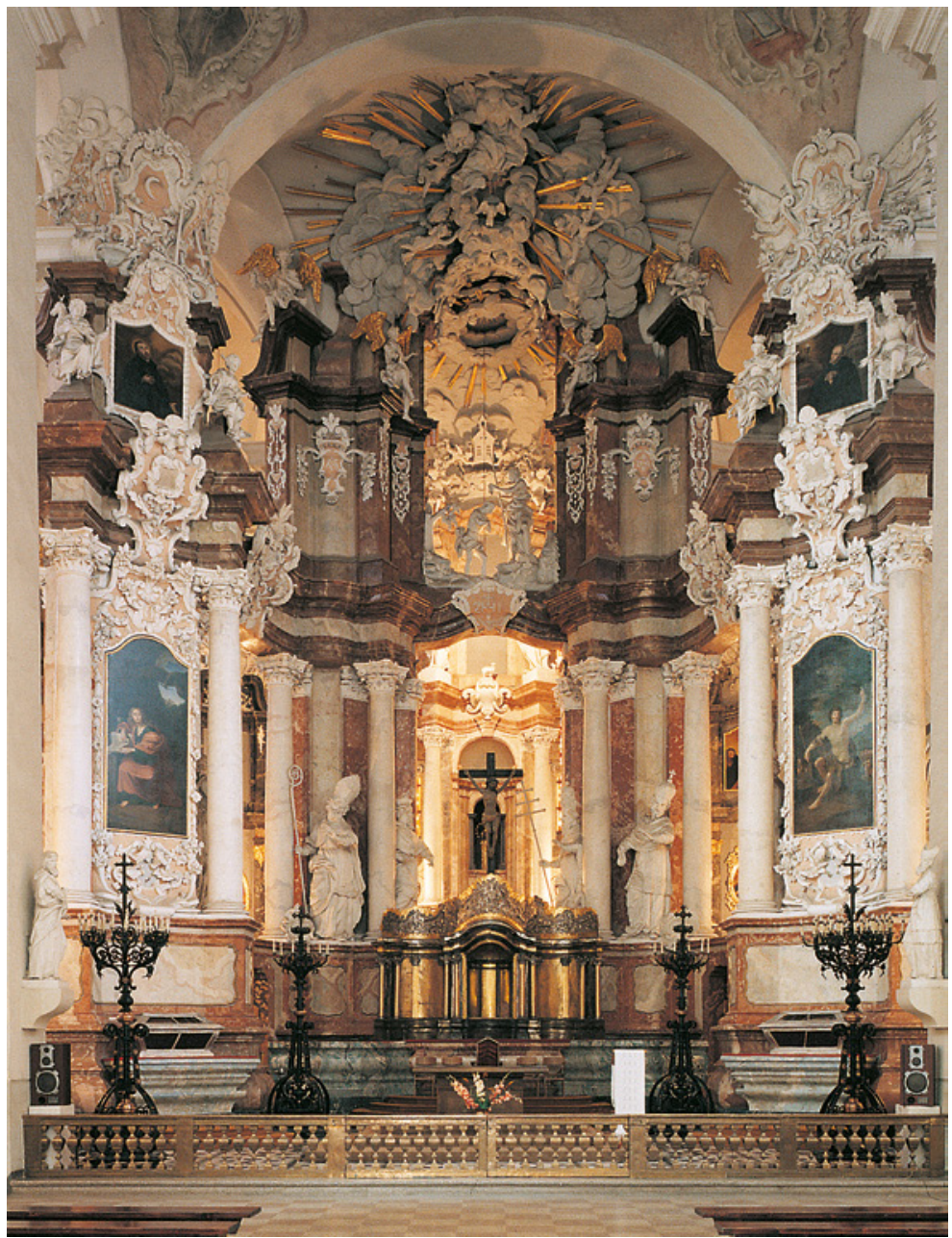

FIGURE 17 Interior of the Jesuit church (St.John) in Vilnius (Wilno), 1751 by Johann Christoph Glaubitz.

PHOTO ANDRZEJ BETLEJ.

1747 and 1752, attributed to Francesco Bartolomeo Rastrelli $[1700-71]) .{ }^{56}$ The next are churches in Polotsk (rebuilt between $175^{1}$ and 1753 by Glaubitz), Vitebsk (dome constructed around 1765), Fashchivka (Faszczówka, facade, 1757), and St. Raphael in Vilnius (towers and interior built between $175^{1}$ and $175^{2}$ by Johann Tobias de Dyderstein [Dietrichstein]). These churches have

$5^{6}$ Kazimierz Głowacki, “Kościół jezuicki w Dźwińsku: Zapomniane dzieło F. B. Rastrellego," Kwartalnik architektury i urbanistyki 31 (1986): 228-49. 


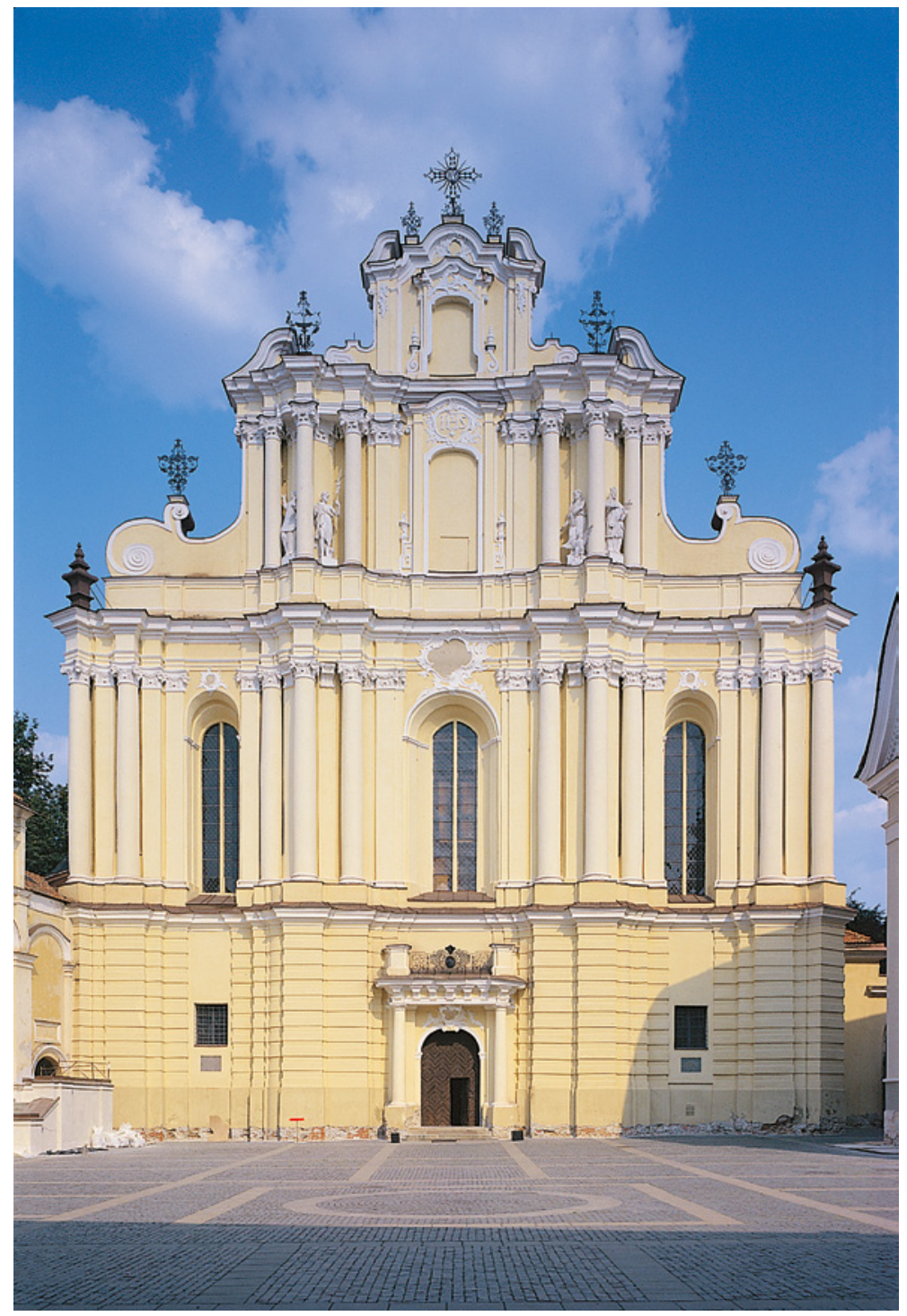

FIGURE 18 Façade of the Jesuit church (St. John) in Vilnius (Wilno), 1748, by Johann Christoph Glaubitz.

PHOTO ANDRZEJ BETLEJ.

very simple, sometimes even conservative plans, but are marked by characteristic, somehow ragged silhouettes, defined by slender towers in the façades, narrowing towards the top. ${ }^{57}$

57 More about the artistic phenomenon of "Vilnius Baroque architecture" see e.g.: Andrzej Baranowski, "Barok wileński na artystycznej mapie Europy środkowej," Biuletyn historii 
After the partitions of Poland (in 1772, 1793, and 1795), there began a period of destruction or deterioration of the architectonic wealth created by the Society of Jesus. The churches were given over to lay clergy. Only in the area taken over by the Russian empire did the order survive until the early nineteenth century, as Tsarina Catherine II (1729-96) forbade the proclamation of the pope's breve suppressing the Society. In this period, the focus of attention was upon the churches located in the easternmost parts of the old Commonwealth. Although the buildings did not employ any particular novelties of design, their importance is chiefly linked to the role of the Society in those regions, notably with the foremost Jesuit school, the Polotsk Academy. It is also worth mentioning that there is a group of churches with unique stylistic features, combining baroque spatial solutions with a decorative costume of classicism, such as the church in Luchai (Łuczaj, finished 1777).

The situation of Jesuit architecture was changing drastically throughout the nineteenth century. The reasons behind these changes were the waves of one Polish national uprising after another, during which the resurgents found refuge in the Roman Catholic Church. Dissolutions following the uprisings of 1830 and 1864 led to the liquidation of many monuments of Jesuit architecture in the eastern lands, especially in the areas belonging to the Russian Empire. Churches were given over to the Russian Orthodox Church, which led to their adaptation and sometimes too drastic remodeling projects, as in Pinsk, Ovruch, and Yurewichi (Jurewicze), among many others. ${ }^{58}$ On the other hand, after the restoration of the Jesuits in 1820 in the areas belonging to the Austrian partition, one can observe the process of an accelerating "reconstruction" of the architectural heritage of the Society. ${ }^{59}$ The further tragic historical events that followed - the First and Second World Wars—annihilated yet more Jesuit churches. The destruction process continued after World War II, particularly in the areas belonging to the Soviet Union.

sztuki 73 (2011): 281-340; Mariusz Karpowicz, "Wileńska odmiana architektury XVIII wieku," Biuletyn historii sztuki 73 (2011): 371-414 (although attributions in these articles should be treated with caution).

$5^{8}$ On the transformation of Jesuit churches to Orthodox churches, see Petro Rychkov, "Interdenominational transmorphism in church architecture of Volhynia," in Między Wroctawiem a Lwowem: Sztuka na Ślasku, w Matopolsce i na Rusi Koronnej w czasach nowożytnych, ed. Andrzej Betlej, Katarzyna Brzezina-Scheuerer, and Piotr Oszczanowski, (Wrocław: Wydawnictwo Uniwersytetu Wrocławskiego, 2011), 391-98.

59 Andrzej Betlej, "Losy budowli pojezuickich na obszarze dawnego województwa ruskiego po likwidacji zakonu," in Losy dziedzictwa po klasztorach jezuickich skasowanych na obszarze Rzeczypospolitej Obojga Narodów oraz jego znaczenie dla powstania i dziatalności Komisji Edukacji Narodowej, ed. Marek Derwich (in print). 
Summing up the above panorama (very general and, consequently, laconic) of the history of Polish Jesuits' architecture, two basic (and obvious) postulates of research should be presented. It is difficult to write the complete panorama without studies or more monographs on the most important artists (e.g. Giacomo Briano or Bartłomiej Nataniel Wąsowski) and without a full analysis of Western European artistic influences on Polish art. It is also necessary to thoroughly examine archives (especially those stored in the archives in Russia, in St. Petersburg, which are difficult to access). 